\title{
Trophic Support of Cultured Spiral Ganglion Neurons by Depolarization Exceeds and Is Additive with that by Neurotrophins or CAMP and Requires Elevation of $\left[\mathrm{Ca}^{2+}\right]_{i}$ within a Set Range
}

\author{
Joseph L. Hegarty, ${ }^{1,2}$ Alan R. Kay, ${ }^{1}$ and Steven H. Green ${ }^{1,2}$ \\ Departments of ${ }^{1}$ Biological Sciences and ${ }^{2}$ Otolaryngology, University of lowa, lowa City, lowa 52242
}

Spiral ganglion neurons (SGNs) require both pre- and postsynaptic contacts to maintain viability. BDNF, NT-3, chlorphenylthioCAMP, and depolarization (veratridine or elevated $\left[\mathrm{K}^{+}\right]_{0}$ ) all promote survival of SGNs in vitro, depolarization being the most effective. Combining different trophic stimuli increases survival in an additive manner. Neurotrophins and depolarization maintain comparable soma size and neurite extension, but SGNs are shrunken in cAMP. Elevated $\left[\mathrm{K}^{+}\right]_{0}$ has a biphasic effect on SGN survival; survival improves as $\left[\mathrm{K}^{+}\right]_{\mathrm{o}}$ is raised to $30 \mathrm{~mm}(30 \mathrm{~K})$ and falls as $\left[\mathrm{K}^{+}\right]_{0}$ is further increased; SGN survival in $80 \mathrm{~mm}\left[\mathrm{~K}^{+}\right]_{0}$ $(80 \mathrm{~K})$ is poor relative to survival in $30 \mathrm{~K}$. These responses to elevated $\left[\mathrm{K}^{+}\right]_{0}$ are potentiated by an L-type channel agonist, whereas L-type $\mathrm{Ca}^{2+}$ channel blockers antagonize the trophic effect of depolarization. Four hours after depolarization, steadystate $\left[\mathrm{Ca}^{2+}\right]_{\mathrm{i}}$ is elevated in SGNs in $30 \mathrm{~K}$ and further elevated in SGNs in 80K. At $22 \mathrm{hr}$ after depolarization, by which time death of neurons in $80 \mathrm{~K}$ has begun, elevated $\left[\mathrm{Ca}^{2+}\right]_{i}$ levels in surviving neurons in $80 \mathrm{~K}$ are not higher than those in neurons in $30 \mathrm{~K}$ ( 150-450 nM), suggesting that neurons with high $\left[\mathrm{Ca}^{2+}\right]_{i}$ are preferentially lost. Veratridine causes oscillatory increases in $\left[\mathrm{Ca}^{2+}\right]_{\mathrm{i}}$ to $250-350 \mathrm{~nm}$. Thus, $\left[\mathrm{Ca}^{2+}\right]_{\mathrm{i}}$ is predictive of cell survival; $\left[\mathrm{Ca}^{2+}\right]_{\mathrm{i}}$ elevated to $100-500 \mathrm{~nm}$ in a sustained or oscillatory manner permits SGN survival independent of exogenous neurotrophic factors. Higher $\left[\mathrm{Ca}^{2+}\right]_{i}$ is associated with cell death.

Key words: depolarization; calcium; neurotrophic factor; neurotrophin; spiral ganglion neuron; cell survival
Neuronal survival is regulated in a complex environment in which neurons are exposed simultaneously to a variety of stimuli, including peptide neurotrophic factors and depolarization. Integration of multiple distinct trophic stimuli may be required for neuronal survival, to achieve specific combinations of signals or to reach a threshold level of trophic signaling. Trophic support derived from both pre- and postsynaptic cells may be required. Presynaptic cells can provide trophic support by releasing neurotrophic factors or neurotransmitters or by depolarization attributable to synaptic activity. Target-derived neurotrophic support has been extensively investigated, but neurotrophic support by presynaptic cells has received less attention.

Spiral ganglion neurons (SGNs) provide a favorable system for experimental investigation of neurotrophic support by presynaptic cells. SGNs are bipolar neurons; a central axon projects to the cochlear nucleus and a peripheral axon to the organ of Corti. Hair cells, the auditory receptors, are the sole presynaptic input to the SGNs. Both pre- and postsynaptic partners are necessary for SGN survival in vivo; neither is sufficient alone. Hair cells can be selectively killed in vivo with aminoglycoside antibiotics, thus deafferenting the SGNs. This results in the eventual death of the

\footnotetext{
Received Sept. 5, 1996; revised Jan. 7, 1997; accepted Jan. 13, 1997.

This study was supported by an American Otological Society Research grant, a University of Iowa CIFRE award, a Carver Scientific Research Initiative grant, and a University of Iowa Diabetes and Endocrinology Research Core Seed grant; and funded by National Institutes of Health (NIH) Grant DK25295 (S.H.G.), NIH Grant NS30654, and a grant from the Office of Naval Research (A.R.K.), and a grant from the Academy of Otolaryngology (J.L.H.). J.L.H. was supported by NIH Training Grant DC00040. We thank Drs. Lloyd Greene and Robin Davis and members of the Green lab for comments on this manuscript, Mr. Matt Cardoni for assisting with the cell counts, and Genentech for graciously providing NT-3.

Correspondence should be addressed to Dr. Steven H. Green, Department of Biological Sciences, University of Iowa, 138 Biology Building, Iowa City, IA 522421324.

Copyright (C) 1997 Society for Neuroscience $0270-6474 / 97 / 171959-12 \$ 05.00 / 0$
}

SGNs (Spoendlin, 1975; Webster and Webster, 1981; Koitchev et al., 1982; Bichler et al., 1983), even though the central projection remains intact. This suggests that different sources of neurotrophic stimuli are summed to a threshold to support survival. One aim of this study is to test this possibility using cultured SGNs. Our data indicate that different types of neurotrophic stimuli are indeed additive.

SGNs express TrkB and TrkC (Ylikoski et al., 1993; Schecterson and Bothwell, 1994) and are supported by BDNF, NT-4, and NT-3 in vitro (Avila et al., 1993; Vazquez et al., 1994; Zheng et al., 1995). SGNs can receive target-derived neurotrophic support by either BDNF or NT-3 in vivo, because both are expressed in the cochlear nucleus (Lefebvre et al., 1994). Type I SGNs can receive presynaptic neurotrophic support from NT-3, expressed in inner hair cells (Ylikoski et al., 1993; Schecterson and Bothwell, 1994).

Electrical activity is another potential source of presynaptic neurotrophic support and has been implicated in neuronal survival in vivo. Blockade of afferent input increases death in vivo in central (Catsicas et al., 1992; Galli-Resta et al., 1993) and peripheral neurons (Wright, 1981; Furber et al., 1987; Meriney et al., 1987; Maderdrut et al., 1988). In the avian auditory system, removal of the cochlea causes rapid atrophic changes, culminating in a $25-30 \%$ loss of neurons in the target, nucleus magnocellularis (Born and Rubel, 1985; Steward and Rubel, 1985; Sie and Rubel, 1992); blockade of electrical activity results in rapid atrophic changes and loss of magnocellularis neurons comparable with those after complete cochlear ablation (Born and Rubel, 1988; Pasic and Rubel, 1989; Rubel et al., 1990; Sie and Rubel, 1992).

Depolarization is also a neurotrophic stimulus in vitro for central and peripheral neurons (Scott and Fisher, 1970; Bennett and White, 1979; Chalazonitis and Fischbach, 1980; Wakade et al., 1983; Gallo et al., 1987); conversely, blockade of electrical activity in vitro reduces neuronal survival (Lipton, 1986; Ruitjer et al., 
1991). The neurotrophic effect of depolarization is apparently a consequence of a sustained rise in cytosolic $\mathrm{Ca}^{2+}$, entering through L-type $\mathrm{Ca}^{2+}$ channels (Gallo et al., 1987; Collins and Lile, 1989; Koike et al., 1989; Collins et al., 1991). This is in spite of the critical role of cytosolic $\mathrm{Ca}^{2+}$ in mediating neuronal degeneration (Choi, 1988; Siesjo et al., 1989). A hypothesis unifying these observations proposes that $\left[\mathrm{Ca}^{2+}\right]_{\mathrm{i}}$ must rise to a particular "setpoint" to promote survival in the absence of neurotrophic factor; degeneration is the result of very high $\left[\mathrm{Ca}^{2+}\right]_{\mathrm{i}}$ (Collins et al., 1991; Koike and Tanaka, 1991; Franklin and Johnson, 1992). Thus, survival occurs within a range of elevated $\left[\mathrm{Ca}^{2+}\right]_{\mathrm{i}}$, with the lower end of the range determined by the $\mathrm{Ca}^{2+}$ setpoint for that neuron and the upper end by that neuron's sensitivity to $\mathrm{Ca}^{2+}$-mediated neurotoxicity. Although this " $\mathrm{Ca}^{2+}$ setpoint" hypothesis can account for neuronal survival in varying levels of sustained depolarization and after exposure to excitotoxins, a recent study of sympathetic neurons (Franklin et al., 1995) found no significant correlation between survival and $\left[\mathrm{Ca}^{2+}\right]_{i}$, inconsistent with the hypothesis.

Investigating the mechanisms of presynaptic neurotrophic support is the second aim of this study. We find that depolarization is a potent source of neurotrophic support for SGNs, more effective than neurotrophins or a permeant cAMP analog. $\mathrm{Ca}^{2+}$ entry via L-type channels is necessary for trophic support by depolarization, and the steady-state level of cytosolic $\mathrm{Ca}^{2+}$ is indeed predictive of cell survival. Our data support a " $\mathrm{Ca}^{2+}$ setpoint" hypothesis and can explain observations (Franklin et al., 1995) not apparently consistent with it.

\section{MATERIALS AND METHODS}

Cell culture and trophic factor deprivation. Dissociated spiral ganglion cell cultures were prepared from postnatal day 5 (P5) Sprague Dawley (Sasco) rat cochleae and maintained using a procedure modified from that described by Lefebvre et al. (1991). The protocol was approved by the University of Iowa Animal Care and Use Committee. Cochleae were aseptically removed from the temporal bone and placed in ice-cold PBS. The bony cochlear capsule was removed, followed by the spiral ligament. The organ of Corti was then removed, transecting the outer radial fibers, leaving the SGNs within the modiolus. Modiolar bone was removed and surrounding connective tissue incompletely removed. Ganglia were collected in ice-cold HBSS. Enzymatic dissociation was then performed in $\mathrm{Ca}^{2+} / \mathrm{Mg}^{2+}$-free HBSS with $0.1 \%$ collagenase, $0.1 \%$ trypsin, and $0.01 \%$ DNase I (Boehringer Mannheim, Indianapolis, IN) in a gently shaking $37^{\circ} \mathrm{C}$ water bath for $25 \mathrm{~min}$. FCS (Life Technologies, Gaithersburg, MD) was added to $10 \%$ to inhibit enzymatic activity, followed by three washes in serum-free DMEM and one wash in culture medium (see below). The ganglia were dissociated mechanically using two fire-polished reducedorifice glass Pasteur pipettes, the second considerably more narrow than the first. The ganglia were gently triturated approximately 15 times with each pipette and diluted with culture medium (8-10 ganglia/2 ml). Cells were allowed to adhere for $4 \mathrm{hr}$ before the addition of trophic factors or other changes made to the culture medium.

Dissociated spiral ganglion cell cultures were maintained in a serumfree culture medium consisting of high-glucose $(4.5 \mathrm{mg} / \mathrm{ml})$ DMEM with $0.1 \mathrm{mg} / \mathrm{ml}$ penicillin and $0.1 \mathrm{mg} / \mathrm{ml}$ streptomycin, in addition to a serumfree supplementation, a modification of the N2 formulation (Bottenstein and Sato, 1979). Our supplementation consisted of human apotransferrin $(100 \mu \mathrm{g} / \mathrm{ml})$, putrescine $(100 \mu \mathrm{M})$, progesterone $(20 \mathrm{nM})$, selenium $(30 \mathrm{~nm})$, crystalline BSA $(20 \mu \mathrm{g} / \mathrm{ml})$, and D-glucose $(1.5 \mathrm{mg} / \mathrm{ml}$; to a final glucose concentration of $6 \mathrm{mg} / \mathrm{ml}$ in the culture medium). Stocks $(100 \times)$ were prepared and kept at $-80^{\circ} \mathrm{C}$. Fresh insulin $(10 \mu \mathrm{g} / \mathrm{ml})$ was added to the supplemental medium on the day of culture. All of these medium supplements were from Sigma (St. Louis, MO). In all chronic elevated $\left[\mathrm{K}^{+}\right]_{\mathrm{o}}$ depolarization experiments, $\mathrm{Na}^{+}$was replaced by equimolar $\mathrm{K}^{+}$to maintain osmolarity.

Cells were cultured in 96-well tissue culture dishes (Falcon) that had been coated sequentially with poly-ornithine $(0.1 \mathrm{mg} / \mathrm{ml}$ in $10 \mathrm{~mm}$ borate buffer, $\mathrm{pH} 8.4$ ) for $1 \mathrm{hr}$ at $20^{\circ} \mathrm{C}$ followed by laminin (mouse EHS, Boehringer Mannheim and Life Technologies, $20 \mu \mathrm{g} / \mathrm{ml}$ in HBSS) over- night at $4^{\circ} \mathrm{C}$. Cells were grown in $100 \mu \mathrm{l}$ medium per well at $37^{\circ} \mathrm{C}$ in a $6.5 \% \mathrm{CO}_{2}$ incubator.

Neuronal survival and neurite growth assay. Spiral ganglion cells were cultured for $48 \mathrm{hr}$ in control or experimental media, then fixed with freshly prepared $4 \%$ paraformaldehyde and $5 \%$ sucrose in $0.1 \mathrm{M}$ phosphate buffer. Fixation was performed at $4{ }^{\circ} \mathrm{C}$ for $30 \mathrm{~min}$, and the cultures were then washed with PBS. The cells were treated with $0.1 \% \mathrm{H}_{2} \mathrm{O}_{2}$ in $100 \%$ methanol for $30 \mathrm{~min}$ at $20^{\circ} \mathrm{C}$ to reduce endogenous peroxidase activity and then washed three times with PBS. The cells were permeabilized using $0.2 \%$ Triton X-100 (Fisher, Houston, TX) in PBS for 30 min at $20^{\circ} \mathrm{C}$. A "blocking buffer" $(2 \% \mathrm{BSA}, 10 \%$ goat serum, and $0.2 \%$ Triton X-100 in PBS) was then added to reduce nonspecific antibody binding. After $45 \mathrm{~min}$ at $37^{\circ} \mathrm{C}$, the blocking buffer was removed and rabbit anti-neuron specific enolase (anti-NSE, Zymed, San Francisco, CA), diluted 1:100 in blocking buffer, was added. Anti-NSE specifically labels neurons and in experiments not shown here labels the same cells as does anti-68 kDa neurofilament antibody. The cells were incubated overnight at $4^{\circ} \mathrm{C}$ in anti-NSE then washed three times with PBS. HRP-conjugated goat anti-rabbit-HRP (Zymed), diluted 1:100 in blocking buffer, was added. After $30 \mathrm{~min}$ at $20^{\circ} \mathrm{C}$, the antibody was removed, and the cultures were washed twice in PBS and once in $0.1 \mathrm{M}$ acetate buffer, $\mathrm{pH}$ 5.2, before adding the chromogen 3-amino-9-ethylcarbazole (Sigma). The AEC (1.25 mM in $0.1 \mathrm{M}$ acetate buffer $+0.03 \% \mathrm{H}_{2} \mathrm{O}_{2}$ ) was allowed to react at room temperature, with the end-point (typically $\sim 5 \mathrm{~min}$ ) determined by monitoring under an inverted microscope, and the reaction terminated by washing with PBS.

SGNs were counted and photographed using a Nikon Diaphot inverted microscope. Counting was done by two individuals. Criteria used to determine neuronal viability were (1) NSE positivity, with a visible nucleus, and (2) absence of nuclear pyknosis. Separate tallies were made of surviving neurons with neurites $\geq 3$ cell diameters in length and those without such neurites. Each trophic factor test was performed in triplicate and repeated on at least three different occasions.

Calcium imaging experiments. Cells were plated in the center of a 25 $\mathrm{mm}$ glass coverslip (Fisher), sequentially coated with poly-ornithine and laminin (as described above), within a small well made with an $8 \times 8 \mathrm{~mm}$ glass cloning cylinder (Bellco) and silicone caulk. The cells were cultured for $2 \mathrm{hr}$ in control medium to allow attachment, then the medium was switched to elevated $\left[\mathrm{K}^{+}\right]_{\mathrm{o}}$ or maintained as control for an additional 4 or $22 \mathrm{hr}$. At 6 or $24 \mathrm{hr}$ after plating, the cells were loaded with $1 \mu \mathrm{M}$ fura-2-acetoxymethyl ester and $0.025 \%$ pluronic acid (Molecular Probes, Eugene, OR) in $0.035 \% \mathrm{DMSO}$ at $37^{\circ} \mathrm{C}$ for $25 \mathrm{~min}$. The cells were then washed three times with $\mathrm{N} 2$ media (containing factors to be studied). The coverslip was clamped into a chamber and then placed in a temperaturecontrolled stage (Medical Systems, Greenvale, NY), held at $37^{\circ} \mathrm{C}$, and superfused with $7 \% \mathrm{CO}_{2} / 93 \%$ air. Viable cells were identified using Hoffman optics and evidence of fura-loading. Neurons were identified by morphology under Hoffman optics. Measurements were taken randomly throughout the culture, obtaining $>100$ cells per condition.

Microfluorimetry was performed on a Nikon Diaphot microscope with excitation provided by two pulsed lasers ( 337 and $380 \mathrm{~nm}, 3 \mathrm{nsec}$ pulse duration, Laser Science, Newton, MA) coupled via a fused quartz light guide to the epi-illumination. The diffused and collimated light was reflected by a dichroic mirror (Omega, 400 DCLP) into the objective (Nikon UV-Fluor, $40 \times$ ). Fluorescence emitted by the cell was transmitted through a $510 \mathrm{~nm}$ edge-pass filter (Omega $510 \mathrm{WB} 40$ ) onto the faceplate of an intensified CCD camera (ICCD 2525FS, Video Scope, Washington, DC). Images were acquired by alternating the firing of the two lasers every $90 \mathrm{msec}$. Intracellular $\mathrm{Ca}^{2+}$ concentrations were estimated using the ratio $R$ of the fluorescent intensity at $337 \mathrm{~nm}$ to that at $380 \mathrm{~nm}$ in the equation of Grynkiewicz et al. (1985):

$$
\left[\mathrm{Ca}^{2+}\right]_{\mathrm{i}}=\frac{S_{\mathrm{f} 2}}{S_{\mathrm{b} 2}} \times\left(K_{\mathrm{D}}\right) \times \frac{\left(R-R_{\min }\right)}{\left(R_{\max }-R\right)},
$$

where $K_{\mathrm{D}}$ is the dissociation constant of fura-2, $R_{\min }$ is the ratio with 0 calcium, $R_{\max }$ is the ratio with saturating calcium, and $S_{\mathrm{f} 2} / S_{\mathrm{b} 2}$ is the ratio of the intensity of fluorescence with $380 \mathrm{~nm}$ excitation for a solution with no calcium divided by that for a solution with saturating calcium. In vitro calibration was performed using a set of buffered $\mathrm{Ca}^{2+}$ concentrations (Molecular Probes). The average intensity of fluorescence over a cell was determined using a rectangular region of interest in the program Transform (Spyglass, Champaign, IL).

Supplies. NT-3 was the generous gift of Genentech (San Francisco, CA). BDNF was purchased from Promega (Madison, WI). BAY K 

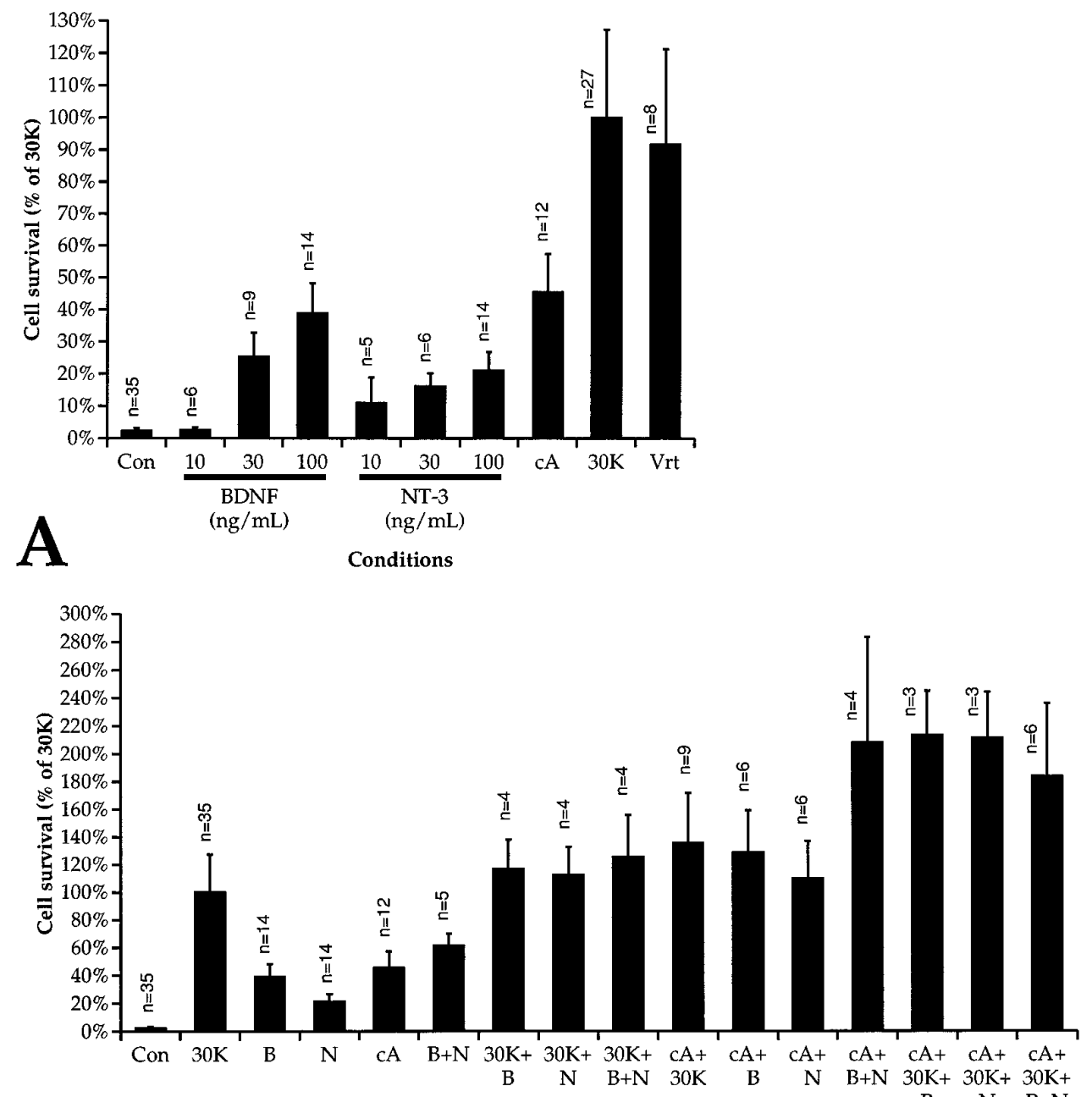

B
Conditions
Figure 1. A, Trophic support of SGNs by neurotrophins, chlorphenylthio-cAMP, and depolarization. Spiral ganglion cultures were fixed and immunostained with anti-NSE, as described in Materials and Methods, after culturing for $48 \mathrm{hr}$ in control DMEM/N2 with no additives (Con), with BDNF or NT-3 at the indicated concentrations, with $1 \mathrm{~mm}$ chlorphenylthiocAMP $(c A)$, with $30 \mathrm{mM}\left[\mathrm{K}^{+}\right]_{\mathrm{o}}(30 K)$, or with $1.5 \mu \mathrm{M}$ veratridine $(V r t)$. Neuronal viability in the experimental conditions is expressed as a percentage of average number of NSE-positive cells in triplicate parallel cultures maintained in $30 \mathrm{~K}$ (arbitrarily defined as $100 \%$ ). The mean value is shown in the figure. All NSE-positive cells were included in these counts, regardless of neurite length. The number of determinations for each condition is shown adjacent to each bar. Each such determination was performed using three separate culture wells. Error bars in this and all subsequent figures indicate SD. $B$, Trophic support of SGNs by combinations of neurotrophins, chlorphenylthio-cAMP, and depolarization. Spiral ganglion cultures were prepared, maintained, and scored for neuronal survival as in $A$, except that trophic agents are added in combinations, as shown, instead of singly. Agents used are $30 \mathrm{~mm}\left[\mathrm{~K}^{+}\right]_{\mathrm{o}}(30 K), 100$ $\mathrm{ng} / \mathrm{ml} \operatorname{BDNF}(B), 100 \mathrm{ng} / \mathrm{ml}$ NT-3 $(N)$, and $1 \mathrm{~mm}$ chlorphenylthio-cAMP $(c A)$.
8644, nifedipine, verapamil, and $\omega$-conotoxin GVIA were obtained from Calbiochem (La Jolla, CA). Chlorphenylthio-cAMP was obtained from Boehringer Mannheim. All culture media were prepared by the University of Iowa Diabetes and Endocrinology Research Center Cell Culture Core, with the exception of the $\mathrm{Ca}^{2+}$-free DMEM, which was obtained from Life Technologies. All other chemicals were obtained from Sigma. Lipid-soluble chemicals were maintained as stocks at $10,000 \times$ working concentration in DMSO, except that BAY K 8644 was dissolved in ethanol. These vehicles alone had no effect on survival at the dilutions used.

\section{RESULTS}

\section{BDNF, NT-3, depolarization, and cAMP rescue SGNs from cell death in vitro}

A single experiment uses dissociated spiral ganglia from five P5 rats plated in 36 wells of a 96-well plate. This yields $800-900$ neurons per well, a plating efficiency of $\sim 13 \%$ given that there are $\sim 24,000$ SGNs in each cochlea of a P5 rat (Rueda et al., 1987).

Neuronal survival was determined by counting NSE-positive cells as described in Materials and Methods. Because NSE is a neuronspecific soluble cytosolic enzyme that should diffuse away from cell debris, we reason that cells positive for NSE immunoreactivity are neurons that must have been alive and intact at the the time of fixation. After $48 \mathrm{hr}$ in culture in N2 medium with no additional trophic agents (control medium), fewer than 10 neurons remained alive in each well. As shown in Figure $1 A$, the neurotrophins NT-3 and BDNF promoted survival in a dose-dependent manner, with the effect saturating at $100 \mathrm{ng} / \mathrm{ml}$, as has been shown previously (Lefebvre et al., 1994; Pirvola et al., 1994; Zheng et al., 1995). The permeant cAMP analog chlorphenylthio-cAMP (cpt-cAMP) promoted survival, with a maximal effect (at $1 \mathrm{mM}$ ), quantitatively comparable with the effect of the neurotrophins.

Cells are depolarized by culturing in medium containing $30 \mathrm{~mm}$ $\mathrm{K}^{+}$or by adding $1.5 \mu \mathrm{M}$ veratridine $\left(\mathrm{Na}^{+}\right.$channel agonist $)$. (External $\mathrm{K}^{+}$concentration is denoted here as $\left[\mathrm{K}^{+}\right]_{\mathrm{o}}$.) Remarkably, depolarization is a much more effective trophic stimulus than is NT-3, BDNF, or cpt-cAMP. Whereas the neurotrophins and cpt-cAMP increase SGN survival by 10 - to 20 -fold over the N2 control, depolarization with $30 \mathrm{~mm}\left[\mathrm{~K}^{+}\right]_{\mathrm{o}}(30 \mathrm{~K})$ or $1.5 \mu \mathrm{M}$ veratridine increases survival by $\sim 40$-fold over control (Fig. 1A). Nerve gowth factor, EGF, and FGF have no trophic effect when added at concentrations up to $100 \mathrm{ng} / \mathrm{ml}$ (data not shown).

These data show that at least four stimuli, BDNF, NT-3, a cAMP analog, and depolarization (mediated by $30 \mathrm{~K}$ or veratridine), are trophic to SGNs. To determine whether the trophic effects are additive, combinations of factors were added to SGNs. Each factor in the combination was present at a level at which it provided its maximal trophic effect. Addition of factors in combination resulted in an increase in SGN survival approximating the arithmetic sum of the survival effect of each factor alone (Fig. $1 B$ ), consistent with an 
additivity of the trophic effects of the different factors. A possible exception to this apparent additivity is that cAMP and neurotrophins appear to interact synergistically: addition of cpt-cAMP in combination with BDNF and NT-3 leads to better SGN survival than might be expected by assuming strict additivity. The survival in these conditions exceeds that in $30 \mathrm{~K}$ with BDNF and NT-3, even though $30 \mathrm{~K}$ alone promotes survival better than does cpt-cAMP alone. However, any such synergistic effect appears to be small relative to the variability among the samples.

\section{SGN soma size and neurites are supported by neurotrophins and depolarization in vitro but are reduced by cpt-cAMP}

SGN appearance was examined in cells cultured under the same conditions as used for the cell counts described above; the cells were plated on polyornithine-laminin in serum-free N2-based medium. The agents shown above to be capable of supporting cell survival were added in various combinations. The cultures were fixed $48 \mathrm{hr}$ after plating and immunostained with anti-NSE, and representative fields photographed under bright-field illumination.

Figure 2 shows examples of the appearance of SGNs cultured under these conditions. SGNs in the presence of any trophic agent generally produced a single neuritic process in vitro, whereas these neurons are bipolar in vivo. Those few neurons that survived in the absence of added neurotrophic agents typically had neurites, although these neurites were relatively short and the cell bodies small. Neurotrophins or depolarization maintained soma size and promoted neurite extension. SGNs depolarized with $30 \mathrm{~K}$, or with veratridine (data not shown), exhibited soma size comparable with that of cells treated with neurotrophins. Although depolarization was more efficacious than neurotrophins at promoting survival, neurite outgrowth in depolarizing conditions was markedly less than in neurotrophins (Fig. 2, Table 1). SGNs treated with combinations of depolarization and neurotrophins show somatic size and neuritic growth comparable with SGNs treated with neurotrophins alone (Fig. 2), in contrast to the significant increment in cell survival observed after combining these agents (Fig. $1 B$ ).

The permeant cAMP analog cpt-cAMP maintained SGN survival but, in contrast to depolarized SGNs or SGNs treated with neurotrophins, SGNs treated with cpt-cAMP had a shrunken appearance with small cell bodies and thin neurites (Fig. 2). The neurites were nearly as long as those of SGNs in neurotrophins (Fig. 2, Table 1). The addition of cpt-cAMP or 30K to neurotrophins resulted in a small reduction in neurite outgrowth relative to that in neurotrophins alone (Table 1). However, the combination of cpt-cAMP and $30 \mathrm{~K}$ strongly reduced SGN neurite outgrowth (Table 1). The reduced size of SGNs treated with cpt-cAMP was not simply attributable to a deficiency of trophic support by cpt-cAMP. SGNs treated with cpt-cAMP in combination with neurotrophins and/or depolarization still exhibited shrunken somata and thin neurites. Therefore, the cAMP analog antagonizes SGN growth regardless of the presence of growth-promoting neurotrophic stimuli.

\section{The trophic effects of depolarization are mediated by $\mathrm{Ca}^{2+}$ entry through L-type $\mathrm{Ca}^{2+}$ channels}

SGNs depolarized with $30 \mathrm{~K}$ or veratridine in the absence of extracellular $\mathrm{Ca}^{2+}$ did not display any increase in survival relative to nondepolarized SGNs (Fig. 3). This suggests that $\mathrm{Ca}^{2+}$ entry through voltage-gated $\mathrm{Ca}^{2+}$ channels, open as a result of the depolarization, is responsible for the trophic effect of depolarization. Nifedipine $(5 \mu \mathrm{M})$ and verapamil $(10 \mu \mathrm{M})$ were used to block dihydropyridine-sensitive L-type $\mathrm{Ca}^{2+}$ channels. Figure 3 shows

\begin{tabular}{|c|c|c|}
\hline Conditions & $\begin{array}{l}\text { SGNs } \\
\text { counted }\end{array}$ & $\begin{array}{l}\text { Neurites } \geq 3 \\
\text { cell diameter }\end{array}$ \\
\hline Control & 1664 & $81.3 \pm 18.6 \%(N=104)$ \\
\hline BDNF (100 ng/ml) & 9310 & $88.8 \pm 6.10 \%(N=42)$ \\
\hline NT-3 (100 ng/ml) & 6603 & $88.9 \pm 6.60 \%(N=54)$ \\
\hline $30 \mathrm{mM}\left[\mathrm{K}^{+}\right]_{\mathrm{o}}$ & 44,892 & $58.1 \pm 13.3 \%(N=90)$ \\
\hline Cpt-cAMP (1 mM) & 9545 & $80.7 \pm 11.0 \%(N=45)$ \\
\hline $30 \mathrm{~K}+\mathrm{BDNF}$ & 15,063 & $78.3 \pm 6.80 \%(N=15)$ \\
\hline $30 \mathrm{~K}+\mathrm{NT}-3$ & 14,238 & $79.6 \pm 5.90 \%(N=15)$ \\
\hline $30 \mathrm{~K}+\mathrm{BDNF}+\mathrm{NT}-3$ & 16,849 & $77.1 \pm 4.20 \%(N=15)$ \\
\hline Cpt-cAMP + BDNF & 10,581 & $79.5 \pm 7.20 \%(N=18)$ \\
\hline Cpt-cAMP + NT-3 & 9168 & $81.1 \pm 8.10 \%(N=18)$ \\
\hline Cpt-cAMP + BDNF + NT-3 & 8005 & $68.8 \pm 24.2 \%(N=12)$ \\
\hline $30 \mathrm{~K}+\mathrm{cpt}-\mathrm{cAMP}$ & 19,489 & $14.3 \pm 6.70 \%(N=30)$ \\
\hline $30 \mathrm{~K}+\mathrm{cpt}-\mathrm{cAMP}+\mathrm{BDNF}$ & 7045 & $20.1 \pm 13.0 \%(N=9)$ \\
\hline $30 \mathrm{~K}+$ cpt-cAMP + NT-3 & 6992 & $24.9 \pm 15.1 \%(N=9)$ \\
\hline $\begin{array}{l}30 \mathrm{~K}+\text { cpt-cAMP }+ \text { BDNF } \\
\quad+\text { NT-3 }\end{array}$ & 13,762 & $18.1 \pm 7.00 \%(N=18)$ \\
\hline
\end{tabular}

Spiral ganglion cultures are fixed and immunostained with anti-NSE, as described in Materials and Methods, after culturing for $48 \mathrm{hr}$ in control DMEM/N2 with no additives (Control) or in DMEM/N2 with $100 \mathrm{ng} / \mathrm{mL}$ BDNF (BDNF), $100 \mathrm{ng} / \mathrm{mL}$ NT-3 (NT-3), $30 \mathrm{mM}\left[\mathrm{K}^{+}\right]_{\mathrm{o}}(30 \mathrm{~K}), 1 \mathrm{mM}$ chlorphenylthio-cAMP, or various combinations of these factors. The cells are viewed in a Nikon Diaphot microscope and separate counts made of SGNs with neurites $\geq 3$ cell diameters and those with shorter neurites. Shown is the total number of cells scored for this purpose and the percentage of these cells with neurites $\geq 3$ cell diameters. The number $N$ used to calculate means and SD values is the number of individual wells used for each determination. The relatively small number of cells per well in the control condition reflects the poor viability of cells in this condition.

that these compounds were effective in blocking the trophic effect of depolarization caused by $30 \mathrm{~K}$, veratridine, or both. Nifedipine and verapamil had no effect on SGN survival in neurotrophins.

Previous studies of cultured guinea pig SGNs have shown that inward $\mathrm{Ca}^{2+}$ currents caused by depolarization are slowly inactivating (Hisashi et al., 1995) and that the increase in $\left[\mathrm{Ca}^{2+}\right]_{\mathrm{i}}$ caused by depolarization is completely blocked by nifedipine or verapamil but is enhanced by Bay K 8644 (Han et al., 1994). These data make it unlikely that depolarization could cause significant $\mathrm{Ca}^{2+}$ influx into SGNs through channels other than L-type. Nonetheless, because $\mathrm{N}$-type channels are expressed on many neurons, we also assessed the effect of the N-type channel blocker $\omega$-conotoxin GVIA $(1 \mu \mathrm{M})$ on cell survival. As shown in Figure 3, $\omega$-conotoxin GVIA had no effect on the ability of $30 \mathrm{~K}$ or veratridine to promote survival. We conclude that $\mathrm{Ca}^{2+}$ influx through L-type $\mathrm{Ca}^{2+}$ channels, specifically, is necessary for the trophic effect of depolarization.

\section{Elevated $\left[\mathrm{K}^{+}\right]_{\mathrm{o}}$ has a biphasic effect on SGN survival}

The survival of SGNs cultured in medium with different $\mathrm{K}^{+}$concentrations was assessed by counting cells as above and is presented in Figure $4 A$. All media used were iso-osmolar with control DMEM/ $\mathrm{N} 2$. Cell survival increased with increasing $\left[\mathrm{K}^{+}\right]_{\mathrm{o}}$ above control (5.4 $\mathrm{mm}\left[\mathrm{K}^{+}\right]_{\mathrm{o}}$ ), reaching a maximum at $30 \mathrm{~mm}\left[\mathrm{~K}^{+}\right]_{\mathrm{o}}$. Above $30 \mathrm{~mm}$ $\left[\mathrm{K}^{+}\right]_{\mathrm{o}}$, survival was reduced; $80 \mathrm{~mm}\left[\mathrm{~K}^{+}\right]_{\mathrm{o}}$ (the highest concentration that can practically be achieved with the culture media we use) had only a marginal effect on SGN survival.

Our data implicate $\mathrm{Ca}^{2+}$ entry through L-type $\mathrm{Ca}^{2+}$ channels in the trophic effect of depolarization on SGNs. This was tested further by using the dihydropyridine L-type $\mathrm{Ca}^{2+}$ channel agonist Bay K $8644(1 \mu \mathrm{M})$. Bay K 8644 potentiated both the survival- 

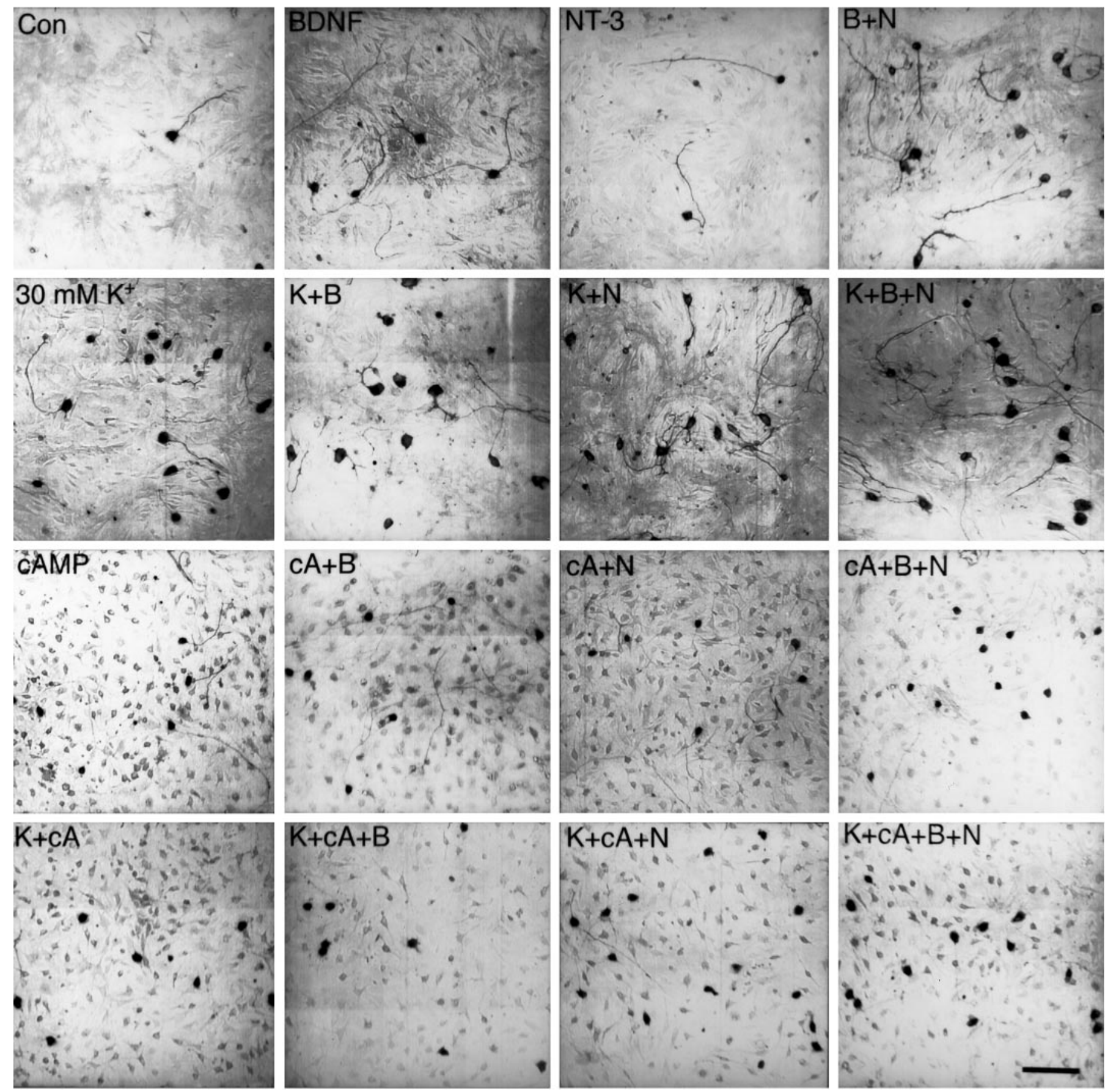

Figure 2. Morphology of SGNs cultured in neurotrophins, chlorphenylthio-cAMP, and 30K. Spiral ganglion cultures were fixed and immunostained with anti-NSE, as described in Materials and Methods, after culturing for $48 \mathrm{hr}$ in control DMEM/N2 with no additives (Con), or in DMEM/N2 with 100 $\mathrm{ng} / \mathrm{ml}$ BDNF $(B), 100 \mathrm{ng} / \mathrm{ml} \mathrm{NT-3}(N), 30 \mathrm{~mm}\left[\mathrm{~K}^{+}\right]_{\mathrm{o}}(K)$, or $1 \mathrm{~mm}$ chlorphenylthio-cAMP $(c A)$. The cells were viewed and photographed in a Nikon Diaphot microscope and photographed under bright-field illumination. The photographs were made at different times with different methods and thus vary in background and contrast. Scale bar (all photographs), $100 \mu \mathrm{m}$.

promoting and survival-inhibiting effects of elevated $\left[\mathrm{K}^{+}\right]_{\mathrm{o}}(\mathrm{Fig}$. $4 B$ ), consistent with a role for the L-type $\mathrm{Ca}^{2+}$ channel. In effect, the relationship of survival to $\left[\mathrm{K}^{+}\right]_{\mathrm{o}}$ was qualitatively similar but shifted to lower values of $\left[\mathrm{K}^{+}\right]_{\mathrm{o}}$ when Bay K 8644 is present. In the presence of Bay K 8644, increased SGN survival was observed in $5.4 \mathrm{~mm}\left[\mathrm{~K}^{+}\right]_{\mathrm{o}}$, the concentration normally present in culture medium. Maximal survival in the presence of Bay K 8644 was at 15 $\mathrm{mm}\left[\mathrm{K}^{+}\right]_{\mathrm{o}}$ instead of $30 \mathrm{~mm}\left[\mathrm{~K}^{+}\right]_{\mathrm{o}}$, and survival declined with $\left[\mathrm{K}^{+}\right]_{\mathrm{o}}>15 \mathrm{~mm}$. However, maximal survival was much less in the presence of Bay K 8644 than in its absence. These data suggest that elevated $\mathrm{Ca}^{2+}$ plays a role in both survival-promoting and survival-inhibiting effects of elevated $\left[\mathrm{K}^{+}\right]_{\mathrm{o}}$, with the effect shifting from survival to toxicity as $\mathrm{Ca}^{2+}$ influx is increased.

Direct measurement of $\left[\mathrm{Ca}^{2+}\right]_{i}$ in depolarized SGNs show a correlation between $\left[\mathrm{Ca}^{2+}\right]_{i}$ and cell survival

The data above show a biphasic dependence of SGN survival on $\left[\mathrm{K}^{+}\right]_{\mathrm{o}}$. If the effects of elevated $\left[\mathrm{K}^{+}\right]_{\mathrm{o}}$ are attributable to an 
Figure 3. The effect of $\mathrm{Ca}^{2+}$ channel blockers and removal of $\left[\mathrm{Ca}^{2+}\right]_{\mathrm{o}}$ on depolarizationdependent survival. Spiral ganglion cultures were prepared, maintained, and scored for neuronal survival after $48 \mathrm{hr}$ in culture, as in Figure 1. The cells were cultured in control DMEM/N2 medium (white bars), 30K depolarizing medium (black bars), or $1.5 \mu \mathrm{M}$ veratridine depolarizing medium (gray bars). In addition, the medium either lacked $\mathrm{Ca}^{2+}$ $(-\mathrm{Ca})$; included $\mathrm{Ca}^{2+}$-channel blockers $5 \mu \mathrm{M}$ nifedipine (Nif), $10 \mu \mathrm{M}$ verapamil $(\mathrm{Vpl})$, or 1 $\mu \mathrm{M} \Omega$-conotoxin GVIA $(\mathrm{Ctx})$; or had no additional modifications (Con). Neuronal viability in the experimental conditions is expressed as a percentage of average number of NSEpositive cells in triplicate parallel cultures maintained in $30 \mathrm{~K}$ depolarizing medium (or veratridine depolarizing medium for veratridine-containing conditions) arbitrarily defined as $100 \%$. The number of determinations for each condition is shown adjacent to each bar.

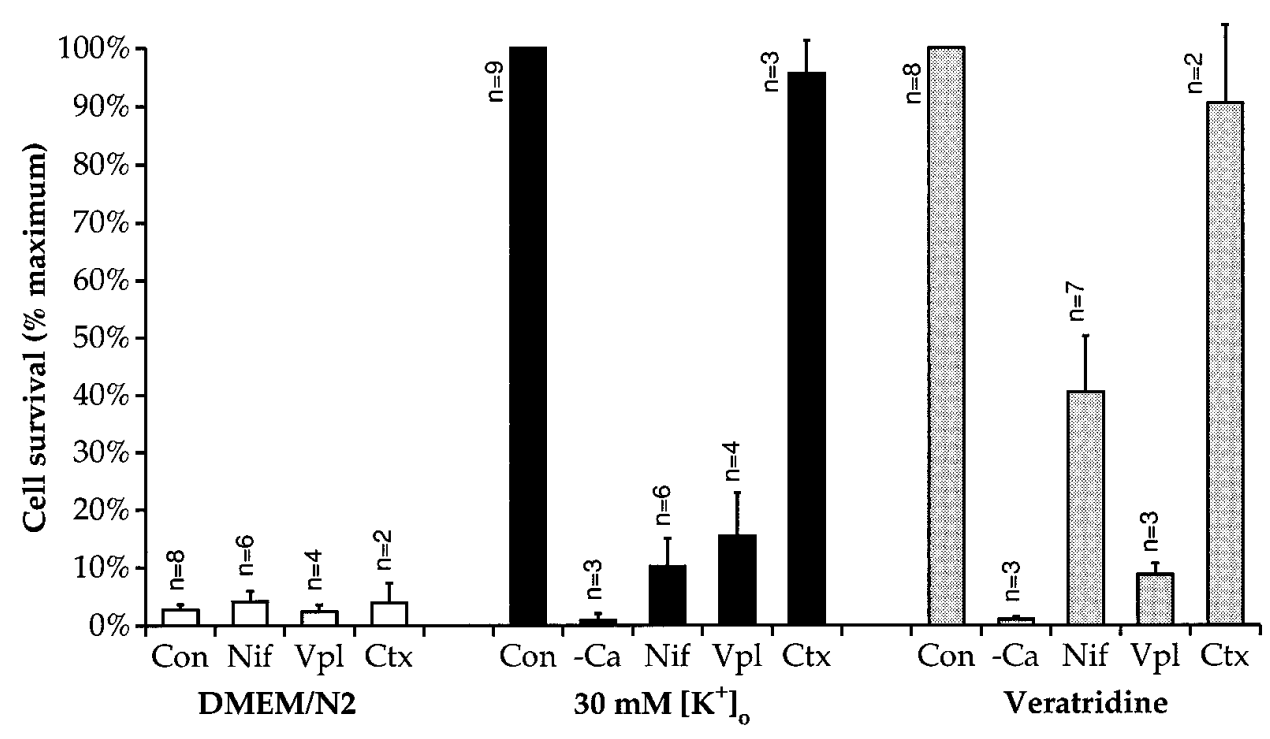

elevated cytosolic $\mathrm{Ca}^{2+}$ concentration (cytosolic $\mathrm{Ca}^{2+}$ concentration is denoted here as $\left.\left[\mathrm{Ca}^{2+}\right]_{\mathrm{i}}\right)$, then cell survival should be correlated with $\left[\mathrm{Ca}^{2+}\right]_{i}$. Previous studies have found such a correlation (Collins et al., 1991; Koike and Tanaka, 1991; Franklin and Johnson, 1992); specifically, increasing $\left[\mathrm{Ca}^{2+}\right]_{\mathrm{i}}$ over the level in nondepolarized cells is associated with cell survival, but very high $\left[\mathrm{Ca}^{2+}\right]_{\mathrm{i}}$ is associated with reduced viability. However, Franklin et al. (1995) recently found that increased $\left[\mathrm{K}^{+}\right]_{\mathrm{o}}$ and consequent depolarized membrane potential was associated with increased survival of sympathetic neurons but that this was not correlated with $\left[\mathrm{Ca}^{2+}\right]_{\mathrm{i}}$ measured $24 \mathrm{hr}$ after initiating depolarization. Rather, the relationship between survival and $\left[\mathrm{Ca}^{2+}\right]_{i}$ was not the same at all values of membrane potential. We measured $\left[\mathrm{Ca}^{2+}\right]_{\mathrm{i}}$ in nondepolarized SGNs and in SGNs depolarized with either $30 \mathrm{~mm}\left[\mathrm{~K}^{+}\right]_{\mathrm{o}}(30 \mathrm{~K})$, which has maximal trophic effect, or 80 $\mathrm{mM}\left[\mathrm{K}^{+}\right]_{\mathrm{o}}(80 \mathrm{~K})$, in which SGN viability is poor. Measurement of $\left[\mathrm{Ca}^{2+}\right]_{\mathrm{i}}$ was performed $4 \mathrm{hr}$ after elevating $\left[\mathrm{K}^{+}\right]_{\mathrm{o}}$, at which time SGNs in all conditions exhibit comparable viability (and $\left[\mathrm{Ca}^{2+}\right]_{\mathrm{i}}$ has already reached steady-state level), and $22 \mathrm{hr}$ after elevating $\left[\mathrm{K}^{+}\right]_{\mathrm{o}}$, at which time neurons in $80 \mathrm{~K}$ exhibit diminished viability relative to those in $30 \mathrm{~K}$.

SGNs respond to depolarization with a biphasic increase in $\left[\mathrm{Ca}^{2+}\right]_{\mathrm{i}}$; there is an initial steep increase in $\left[\mathrm{Ca}^{2+}\right]_{\mathrm{i}}$ followed by gradual decline to a steady-state level, which is maintained thereafter (Han et al., 1994). This plateau value $(\sim 0.5 \mu \mathrm{M})$ is comparable with the mean $\left[\mathrm{Ca}^{2+}\right]_{i}$ level that we find in SGNs depolarized for $4 \mathrm{hr}$ and therefore can be considered a "steady-state" value.

SGNs cultured for $2 \mathrm{hr}$ in control medium $\left(5.4 \mathrm{~mm}\left[\mathrm{~K}^{+}\right]_{\mathrm{o}}\right)$ and then for $4 \mathrm{hr}$ in control medium, in $30 \mathrm{~K}$ or $80 \mathrm{~K}$, exhibited comparable viability. SGNs cultured for $6 \mathrm{hr}$ in control medium $\left(5.4 \mathrm{~mm}\left[\mathrm{~K}^{+}\right]_{\mathrm{o}}\right)$ had a mean $\left[\mathrm{Ca}^{2+}\right]_{\mathrm{i}}=110 \mathrm{nM}(\mathrm{SD}=66 \mathrm{nM}, n=$ 134) (Fig. 5). SGNs exposed to elevated $\left[\mathrm{K}^{+}\right]_{\mathrm{o}}$ for $4 \mathrm{hr}$ exhibited $\left[\mathrm{Ca}^{2+}\right]_{\mathrm{i}}$ greatly elevated over control (Fig. 5). The histograms show that there were very few SGNs in either $30 \mathrm{~K}$ or $80 \mathrm{~K}$, with $\left[\mathrm{Ca}^{2+}\right]_{\mathrm{i}}$ levels comparable with those of SGNs in control medium. In either $30 \mathrm{~K}$ or $80 \mathrm{~K}$, the elevated $\left[\mathrm{Ca}^{2+}\right]_{\mathrm{i}}$ levels were very widely distributed. In $30 \mathrm{~K}$, the average $\left[\mathrm{Ca}^{2+}\right]_{\mathrm{i}}$ was $571 \mathrm{nM}$ with an SD of $233 \mathrm{~nm}(n=110)$ and in $80 \mathrm{~K}$, the average $\left[\mathrm{Ca}^{2+}\right]_{\mathrm{i}}$ was $922 \mathrm{~nm}$ with an SD of $393 \mathrm{~nm}(n=101)$, but the range of $\left[\mathrm{Ca}^{2+}\right]_{\mathrm{i}}$ values was so great that the average value has little significance. However, the histograms in Figure 5 show that neuronal $\left[\mathrm{Ca}^{2+}\right]_{\mathrm{i}}$ levels are higher in $80 \mathrm{~K}$ than in $30 \mathrm{~K}$; most of the SGNs in $80 \mathrm{~K}$ have higher $\left[\mathrm{Ca}^{2+}\right]_{\mathrm{i}}$ than most of the neurons in $30 \mathrm{~K}$, although some overlap exists. These data are consistent with the hypothesis that $\left[\mathrm{Ca}^{2+}\right]_{i}$ is predictive of cell fate, with either very low $\left[\mathrm{Ca}^{2+}\right]_{i}$ (i.e., $<100-$ $200 \mathrm{nM})$ or very high $\left[\mathrm{Ca}^{2+}\right]_{\mathrm{i}}$ (i.e., $>600-700 \mathrm{nM}$ ), incompatible with neuronal viability. The cytotoxicity of high $\left[\mathrm{Ca}^{2+}\right]_{i}$ could account for poor survival in $80 \mathrm{~K}$.

The levels of $\left[\mathrm{Ca}^{2+}\right]_{i}$ in SGNs continuously depolarized for 22 $\mathrm{hr}$ in $80 \mathrm{~K}$ were significantly different from those in cells depolarized for $4 \mathrm{hr}$ (Fig. 6). SGNs in control medium $\left(5.4 \mathrm{~mm}\left[\mathrm{~K}^{+}\right]_{\mathrm{o}}\right)$ had an average $\left[\mathrm{Ca}^{2+}\right]_{\mathrm{i}}=39 \mathrm{nM}(\mathrm{SD}=30 \mathrm{nM}, n=138)$, whereas for SGNs in $30 \mathrm{~K}$, the average $\left[\mathrm{Ca}^{2+}\right]_{\mathrm{i}}$ was $316 \mathrm{~nm}$ with an SD of 164 $\mathrm{nM}(n=138)$, and in $80 \mathrm{~K}$, the average $\left[\mathrm{Ca}^{2+}\right]_{\mathrm{i}}$ was $285 \mathrm{~nm}$ with an $\mathrm{SD}$ of $202 \mathrm{~nm}(n=190)$. As was the case after $4 \mathrm{hr}$ of depolarization, the levels of $\left[\mathrm{Ca}^{2+}\right]_{i}$ were very widely distributed. After 22 $\mathrm{hr}$ in $80 \mathrm{~K},>30 \%$ of the SGNs have already died (M. Hansen and $\mathrm{S}$. Green, unpublished observations) and $>80 \%$ die within $48 \mathrm{hr}$ (Fig. 4A). The distribution of $\left[\mathrm{Ca}^{2+}\right]_{\mathrm{i}}$ levels in the surviving SGNs after $22 \mathrm{hr}$ in $80 \mathrm{~K}$ is similar to that in SGNs in $30 \mathrm{~K}$. Relatively few cells exhibited very high $\left[\mathrm{Ca}^{2+}\right]_{i}$, as was the case after $4 \mathrm{hr}$ in $80 \mathrm{~K}$. This suggests that the cells lost are expressly those with high $\left[\mathrm{Ca}^{2+}\right]_{\mathrm{i}}$ or that SGNs alter their regulation of $\left[\mathrm{Ca}^{2+}\right]_{\mathrm{i}}$ with time in culture under these conditions.

A population of SGNs with low $\left[\mathrm{Ca}^{2+}\right]_{\mathrm{i}}$ was observed in cultures depolarized with $80 \mathrm{~K}$, but not with $30 \mathrm{~K}$ (Fig. 6). This may reflect long-term changes in $\mathrm{Ca}^{2+}$ influx, transport, or buffering in these cells.

Cells cultured with $1 \mu \mathrm{M}$ Bay K 8644 survived best in $15 \mathrm{~mm}$ $\left[\mathrm{K}^{+}\right]_{\mathrm{o}}$ (Fig. $4 B$ ). $\left[\mathrm{Ca}^{2+}\right]_{\mathrm{i}}$ levels in SGNs cultured in $1 \mu \mathrm{M}$ Bay $\mathrm{K}$ $8644+15 \mathrm{~mm}\left[\mathrm{~K}^{+}\right]_{\mathrm{o}}$ for $22 \mathrm{hr}$ are shown in Figure 7. SGNs so cultured had $\left[\mathrm{Ca}^{2+}\right]_{\mathrm{i}}$ levels comparable with SGNs treated with $30 \mathrm{~K}$ (compare Fig. 6). In $1 \mu \mathrm{M}$ Bay K $8644+15 \mathrm{~mm}\left[\mathrm{~K}^{+}\right]_{\mathrm{o}}$, the average $\left[\mathrm{Ca}^{2+}\right]_{\mathrm{i}}$ was $371 \mathrm{~nm}$, with an SD of $183 \mathrm{~nm}(n=83)$. The addition of $1 \mu \mathrm{M}$ Bay $\mathrm{K} 8644$ to control medium $\left(5.4 \mathrm{~mm}\left[\mathrm{~K}^{+}\right]_{\mathrm{o}}\right)$ resulted in oscillations in $\left[\mathrm{Ca}^{2+}\right]_{\mathrm{i}}$ from control levels to $150-200$ $\mathrm{nm}$ (data not shown). These oscillatory increases in $\left[\mathrm{Ca}^{2+}\right]_{i}$ may account for the small enhancement of SGN survival observed in 1 $\mu \mathrm{M}$ Bay K 8644 (Fig. 4B). The behavior of SGNs in $1 \mu \mathrm{M}$ Bay K 8644 was thus unlike the behavior of SGNs depolarized by $30 \mathrm{~K}$, $80 \mathrm{~K}$, or $1 \mu \mathrm{M}$ Bay K $8644+15 \mathrm{~mm}\left[\mathrm{~K}^{+}\right]$, which consistently 

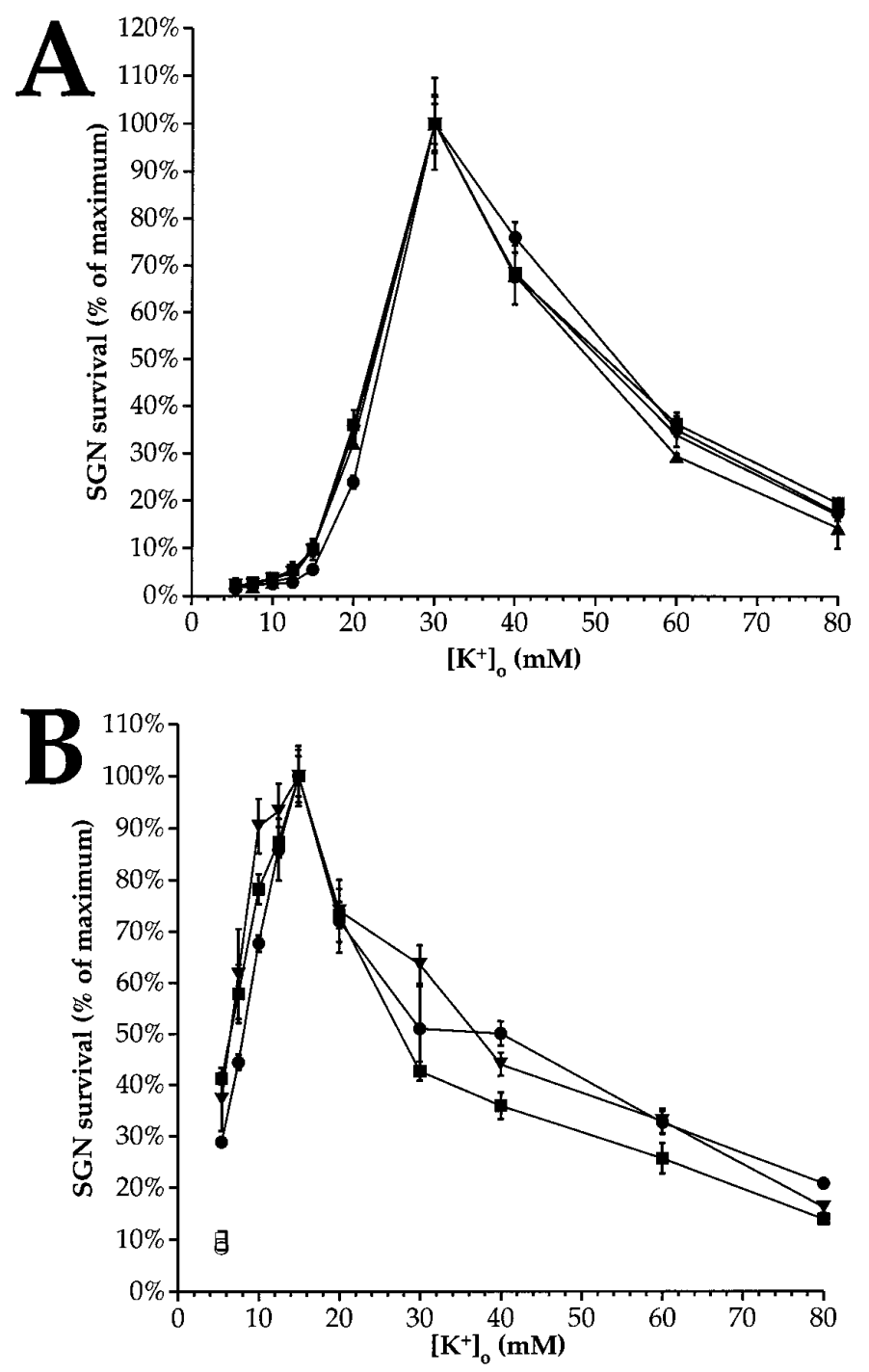

Figure 4. Spiral ganglion neuronal survival as a function of $\left[\mathrm{K}^{+}\right]_{\mathrm{o}}$. Spiral ganglion cultures were prepared, maintained, and scored for neuronal survival after $48 \mathrm{hr}$ in culture, as in Figure 1, with survival in $30 \mathrm{~mm}\left[\mathrm{~K}^{+}\right]_{\mathrm{o}}$ (maximal survival) defined as $100 \%$. The culture medium was DMEM/N2 with $\mathrm{Na}^{+}$replaced with equimolar $\mathrm{K}^{+}$to achieve the indicated values of $\left[\mathrm{K}^{+}\right]_{\mathrm{o}}$. Each of the four individual plots represents a separate experiment, and each point represents the mean of triplicate wells counted. $B$, Spiral ganglion neuronal survival as a function of $\left[\mathrm{K}^{+}\right]_{\mathrm{o}}$ in Bay $\mathrm{K} 8644$. SGN viability in different $\left[\mathrm{K}^{+}\right]_{\mathrm{o}}$ values was assessed as in $A$, except that the L-type $\mathrm{Ca}^{2+}$ channel agonist Bay K $8644(1 \mu \mathrm{M})$ was added (solid symbols). Neuronal viability in the experimental conditions is expressed as in $A$, except that survival in $15 \mathrm{~mm}\left[\mathrm{~K}^{+}\right]_{\mathrm{o}}$ (the condition at which survival was maximal with $1 \mu \mathrm{M}$ Bay K 8644) was defined as $100 \%$. Survival determinations in control medium without Bay K 8644 are represented by open symbols. Each of the three individual plots represents a separate experiment, and each point represents the mean of triplicate wells counted.

exhibited stable nonoscillating $\left[\mathrm{Ca}^{2+}\right]_{\mathrm{i}}$ regardless of the variability in the level of steady-state $\left[\mathrm{Ca}^{2+}\right]_{\mathrm{i}}$ among the SGNs.

The $\mathrm{Na}^{+}$channel agonist veratridine $(1.5 \mu \mathrm{M})$ was approximately equal to $30 \mathrm{~K}$ in the ability to promote SGN survival (Fig. 1). However, veratridine caused oscillatory increases in $\left[\mathrm{Ca}^{2+}\right]_{i}$, an oscillation that began at application of the drug (data not shown) and persisted for at least $24 \mathrm{hr}$. Four representative examples of SGNs cultured for $24 \mathrm{hr}$ in medium containing $1.5 \mu \mathrm{M}$ veratridine are shown in Figure 8 . The
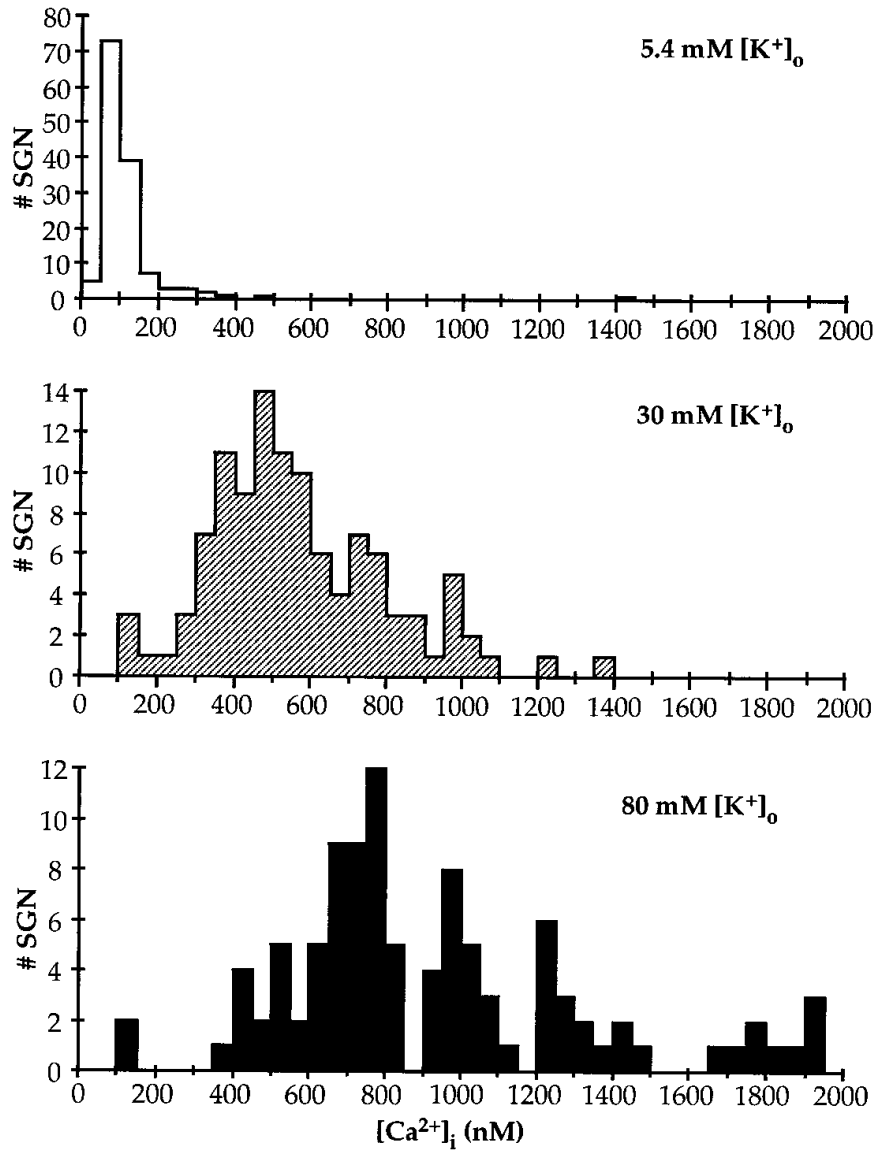

Figure 5. $\left[\mathrm{Ca}^{2+}\right]_{\mathrm{i}}$ histograms after $6 \mathrm{hr}$ in 5.4 (control), 30, or $80 \mathrm{~mm}$ $\left[\mathrm{K}^{+}\right]_{\mathrm{o}}$. Spiral ganglia were dissociated and the cells plated on polyornithine/laminin-coated glass coverslips as described in Materials and Methods. Elevated $\left[\mathrm{K}^{+}\right]_{\mathrm{o}}$ medium was added $2 \mathrm{hr}$ after plating. $\left[\mathrm{Ca}^{2+}\right]_{\mathrm{i}}$ was determined from the ratio of Fura-2 fluorescence at 337 and $380 \mathrm{~nm}$, as described in Materials and Methods. The images captured were from fields randomly distributed on the coverslip. Ratios (256) of each field, taken at $90 \mathrm{msec}$ intervals, were averaged. A sufficient number of fields were imaged to to allow assay of $\left[\mathrm{Ca}^{2+}\right]_{i}$ in $>100$ neurons for each condition. All of the images were captured within an interval of $30 \mathrm{~min}$. Two to three coverslips were used for each condition, assayed on different days. The calculated $\left[\mathrm{Ca}^{2+}\right]_{\mathrm{i}}$ values, grouped in $50 \mathrm{~nm}$ bins, are plotted in the histograms shown.

oscillatory increases in $\left[\mathrm{Ca}^{2+}\right]_{\mathrm{i}}$ are up to $250-350 \mathrm{~nm}\left[\mathrm{Ca}^{2+}\right]_{\mathrm{i}}$, greater than the peak $\left[\mathrm{Ca}^{2+}\right]_{\mathrm{i}}$ levels observed in SGNs in $1 \mu \mathrm{M}$ Bay K $8644+5.4 \mathrm{~mm}\left[\mathrm{~K}^{+}\right]_{\mathrm{o}}$.

From these data, it appears that the initial steady-state level of $\left[\mathrm{Ca}^{2+}\right]_{\mathrm{i}}$ is predictive of SGN survival. The level seen after $24 \mathrm{hr}$ reflects that in those SGNs selected for ability to survive in the particular depolarizing condition. Apparently, these are the neurons having $\left[\mathrm{Ca}^{2+}\right]_{\mathrm{i}}$ in the range displayed in the histograms in Figures 7 and $8, \sim 150-450 \mathrm{~nm}$, which can be considered the range permissive for survival in vitro in the absence of exogenous neurotrophic factors.

\section{DISCUSSION}

\section{Trophic support by neuronal afferents can involve neurotrophic factors, cAMP, and membrane electrical activity}

SGNs die after deafferentation in vivo and after isolation in culture. In either case, the death is apparently apoptotic ( $\mathrm{J}$. Hegarty and S. Green, unpublished observations), characteristic 

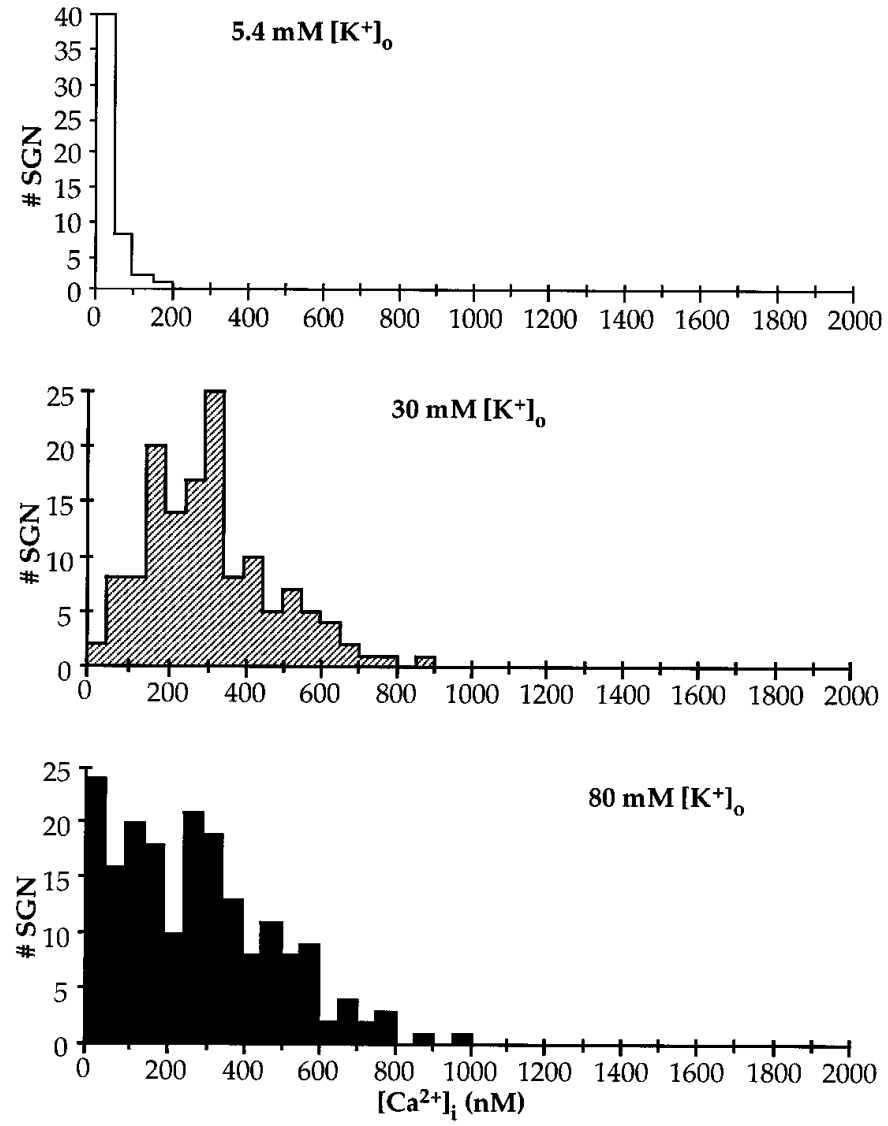

Figure 6. $\left[\mathrm{Ca}^{2+}\right]_{\mathrm{i}}$ histograms after $24 \mathrm{hr}$ in 5.4 (control), 30 , or $80 \mathrm{~mm}$ $\left[\mathrm{K}^{+}\right]_{\mathrm{o}}$. $\left[\mathrm{Ca}^{2+}\right]_{\mathrm{i}}$ levels in dissociated SGNs were determined as in Figure 5. The calculated $\left[\mathrm{Ca}^{2+}\right]_{\mathrm{i}}$ values, grouped in $50 \mathrm{~nm}$ bins, are plotted in the histograms shown. To facilitate comparison, the abscissae are at the same scale as in the histograms in Figure 5.

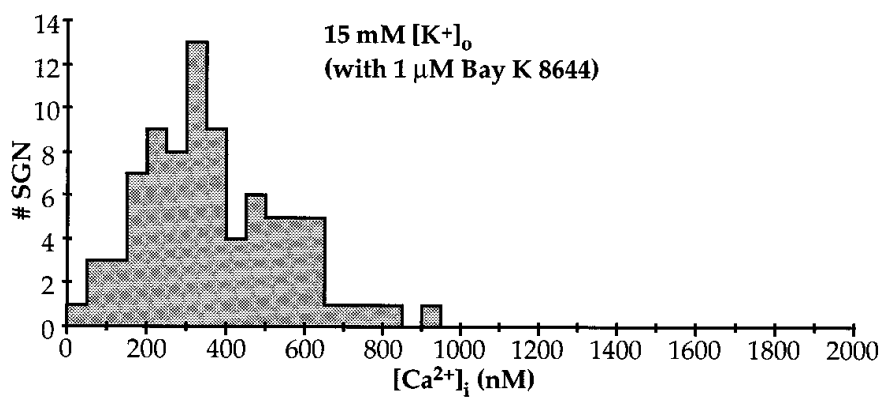

Figure 7. $\left[\mathrm{Ca}^{2+}\right]_{\mathrm{i}}$ histograms after $24 \mathrm{hr}$ in $15 \mathrm{~mm}\left[\mathrm{~K}^{+}\right]_{\mathrm{o}}+1 \mu \mathrm{M}$ Bay $\mathrm{K}$ 8644. $\left[\mathrm{Ca}^{2+}\right]_{\mathrm{i}}$ levels in dissociated SGN were determined as in Figure 5. The calculated $\left[\mathrm{Ca}^{2+}\right]_{\mathrm{i}}$ values, grouped in $50 \mathrm{~nm}$ bins, are plotted in the histograms shown. To facilitate comparison, the abscissae are at the same scale as in the histograms in Figures 5 and 6.m

of neurons that have lost trophic support (Johnson and Deckworth, 1993). Studies of auditory system reveal that pre- and postsynaptic sources of neurotrophic support cooperate to prevent programmed cell death. Type I SGNs, which constitute $>90 \%$ of the population, receive presynaptic input from the inner hair cells and are dependent on them for survival (Spoendlin, 1975; Webster and Webster, 1981; Koitchev et al., 1982; Bichler et al., 1983). As with other cells in the vicinity of the neuron and its terminals, presynaptic cells can contribute to neuronal survival by
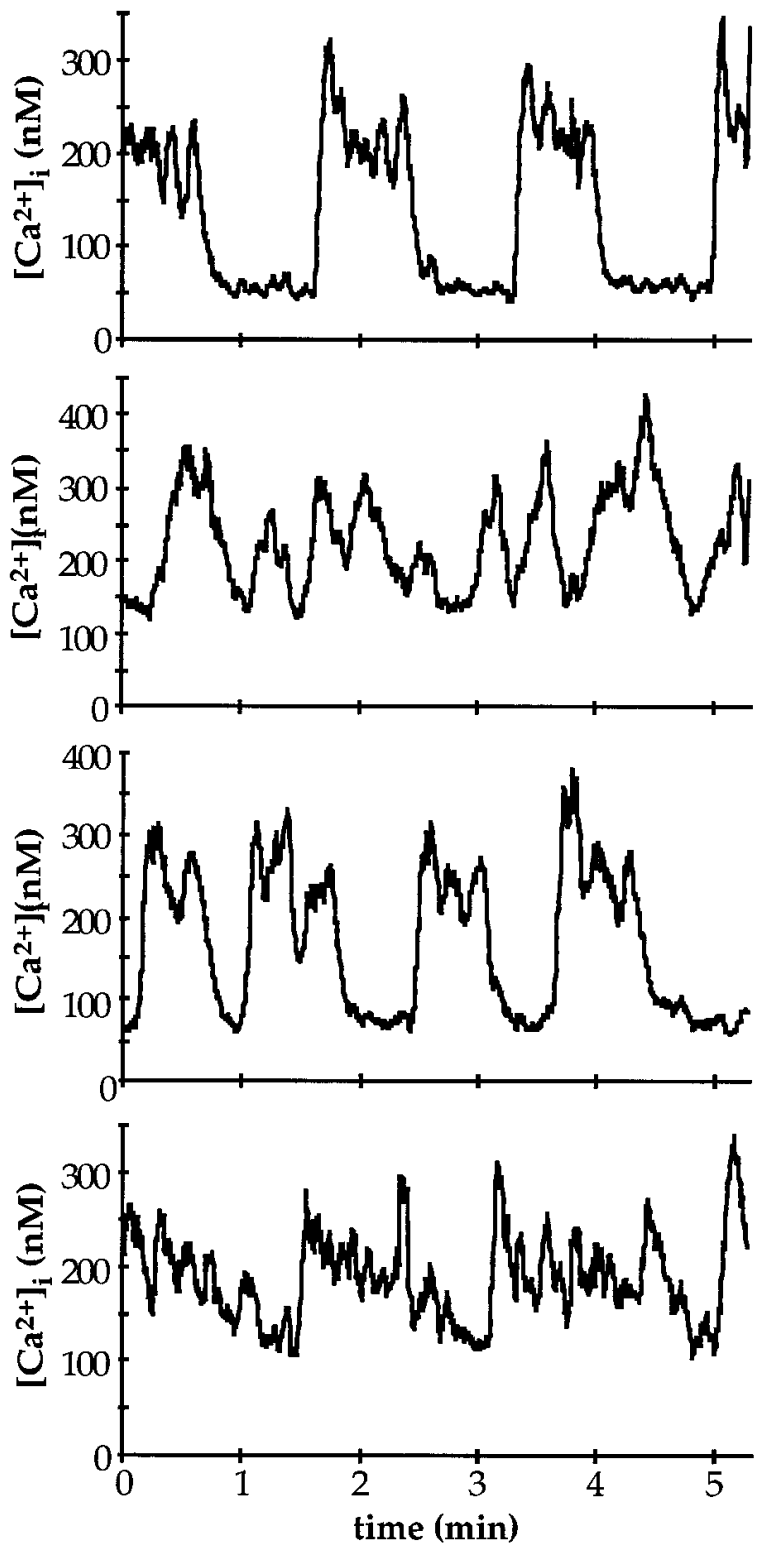

Figure 8. Veratridine-induced $\left[\mathrm{Ca}^{2+}\right]_{\mathrm{i}}$ oscillations in SGN. $\left[\mathrm{Ca}^{2+}\right]_{\mathrm{i}}$ levels in dissociated SGNs were determined as in Figure 5 and plotted as a function of time. Ratios were acquired every $240 \mathrm{msec}$ for rectangular areas of interest overlying the neurons. Records from four different neurons are shown here.

releasing neurotrophic factors. In addition, presynaptic cells can provide neurotrophic support by causing depolarization through synaptic activity or by releasing neurotransmitters that activate trophic second messenger systems. The cochlea is well suited as a system for study of the means by which presynaptic input contributes to neuronal survival, because the SGNs are relatively accessible to in vivo experimental manipulations, including deafferentation and direct electrical stimulation (Wong-Riley et al., 1981; Lousteau, 1987; Hartshorn et al., 1991; Leake et al., 1991, 1992; Lustig et al., 1994).

\section{Support by neurotrophins}

The embryonic rat auditory sensory epithelium expresses BDNF and NT-3 (Wheeler et al., 1994). However, the SGNs, which 
express both TrkB and TrkC (Ylikoski et al., 1993; Pirvola et al., 1994; Schecterson and Bothwell, 1994), require only NT-3 for survival. Mice homozygous for NT-3 knockout are born lacking $>85 \%$ of the SGNs (Fariñas et al., 1994; Ernfors et al., 1995), whereas mice homozygous for BDNF knockout show only a small loss of SGNs at birth (Conover et al., 1995; Ernfors et al., 1995). Nonetheless, BDNF, like NT-3, supports survival of cultured embryonic and postnatal SGNs (Avila et al., 1993; Lefebvre et al., 1994; Pirvola et al., 1994; Vazquez et al., 1994; Zheng et al., 1995). It is not clear why only NT-3, and not BDNF, is necessary for prenatal trophic support of SGNs; possibly, SGNs lack access to sufficient BDNF at this time.

We show here that BDNF and NT-3 are trophic to P5 rat SGNs in vitro, consistent with previous studies that showed that BDNF, NT-3, and NT-4 are trophic to postnatal SGNs (Lefebvre et al., 1994; Vazquez et al., 1994; Zheng et al., 1995). At P5, NT-3 expression is low in auditory hair cells, and BDNF is not expressed (Pirvola et al., 1994; Wheeler et al., 1994), concomitant with a postnatal reorganization of afferent SGN synapses and period of SGN death during which $\sim 20 \%$ of SGNs are lost (Rueda et al., 1987). In mature organ of Corti, NT-3 is expressed in the inner hair cells, and BDNF is not expressed (Ylikoski et al., 1993; Pirvola et al., 1994; Schecterson and Bothwell, 1994; Wheeler et al., 1994). Thus, if a hair cell-derived neurotrophin is necessary for support of mature type I SGNs, it is NT-3. BDNF is produced in the cochlear nucleus (Lefebvre et al., 1994) and can supply postsynaptic trophic support.

\section{Support by nerve membrane electrical activity}

Direct electrical stimulation is sufficient to promote survival of deafferented SGNs in vivo (Wong-Riley et al., 1981; Lousteau, 1987; Hartshorn et al., 1991; Leake et al., 1991, 1992; Lustig et al., 1994). The present study, using an in vitro model, support the hypothesis that membrane electrical activity attributable to presynaptic input is a crucial source of trophic support for SGNs. Membrane depolarization is a significant neurotrophic stimulus for cultured SGNs, as it is for other neurons. Indeed, SGNs exhibit markedly greater survival in depolarizing conditions than in neurotrophins.

Although trophic to sympathetic neurons, depolarization did not support somatic or neuritic growth (Franklin et al., 1995). This does not appear to be a general property of neurons; SGNs maintained in depolarizing media displayed somatic and neuritic growth comparable with that of SGNs maintained in neurotrophins. This difference may be attributable to differences in culture conditions (the SGNs were plated on laminin and the sympathetic neurons on other substrates) or to differences between the cells. For instance, membrane electrical activity promotes neurotrophin synthesis in SGNs (M. Hansen and S. Green, unpublished observations) possibly allowing support of neurite outgrowth by an autocrine effect. In contrast, Franklin et al. (1995) could not detect a depolarization-induced neurotrophin autocrine mechanism in sympathetic neurons.

\section{Support by cAMP analogs}

Permeant cAMP analogs have been shown previously to promote sympathetic neuronal survival (Rydel and Greene, 1988). This may be relevant to support by afferent input in vivo, because neurotransmitters can stimulate adenylate cyclase activity. We show here that cpt-cAMP promoted SGN survival and neurite length comparable with that in neurotrophins, but cell somata and neurites appeared shrunken and thin, unlike their appearance in
30K or neurotrophins. Rydel and Greene (1988) found that NGF promoted sympathetic neuron somatic hypertrophy and neurite growth to a much greater degree than did cAMP analogs. However, in sympathetic neurons, cAMP analogs did not antagonize somatic or neuritic growth promoted by NGF nor antagonize growth in neurons plated on laminin, whereas SGNs maintained with cpt-cAMP have shrunken somata and thin neurites, even in the presence of laminin and neurotrophins. Apparently, a growthinhibiting activity of cAMP is antagonized by exogenous growthpromoting factors, such as NGF or laminin, in sympathetic neurons, but not in SGNs. In PC12 cells, cAMP antagonizes neurite outgrowth in the presence of NGF (Greene et al., 1986), an even stronger inhibitory effect than what is observed SGNs. A strong inhibition of neurite outgrowth in cultured SGNs is observed in the presence of both cAMP and depolarization, possibly attributable to summation of inhibitory stimuli that separately have only a small effect on SGNs.

\section{Additivity can account for the requirement for multiple sources of trophic support by SGNs in vivo}

Our observation that depolarization in vitro is a more potent trophic stimulus than neurotrophins or cAMP analogs is consistent with the possibility that electrical stimulation is the primary trophic stimulus provided by afferent neurons in vivo. However, the observation of additivity and, possibly, some synergism among the various neurotrophic agents that we used suggests that, in vivo, it is the combination of trophic stimuli received from all pre- and postsynaptic sources that is necessary to fully promote survival. The observed additivity in neurotrophic support by various stimuli could reflect the existence of different subpopulations of SGNs, each supported by a different stimulus. Because additional increments of trophic support were provided by each of four different stimuli, there would have to be at least four different SGN subpopulations to account for our results. Although formally possible, this is an unlikely possibility.

Additivity or synergism among different neurotrophic stimuli is likely to be attributable to interactions among the intracellular signal pathways that they use. There are at least two types of interactions. First, summation of neurotrophic effects may result from increased magnitude or duration in a single intracellular signal pathway. This can account for the additivity reported here or for possible synergism (R. Davis, personal communication) in the neurotrophic effects of BDNF and NT-3. Both signal through Trk family protein-tyrosine kinases and thus are likely to activate the same intracellular signaling pathways to promote survival. Second, summation may be attributable to activation of different intracellular signaling pathways by different neurotrophic stimuli. $\mathrm{Ca}^{2+}$ and cAMP function in intracellular pathways that are distinct from each other and from the pathway used by neurotrophin signal transduction. Trophic support of sympathetic or sensory neurons by NGF does not require cAMP signaling (Rydel and Greene, 1988), nor does trophic support of cerebellar granule cells by peptide growth factors of cAMP require increased $\left[\mathrm{Ca}^{2+}\right]_{i}$ (Galli et al., 1995). Additivity among depolarization, peptide neurotrophic factor, and substratum in the trophic support of cultured ciliary ganglion neurons (Schmidt and Kater, 1993) appears to depend on the recruitment of different intracellular signals by laminin and depolarization (Schmidt and Kater, 1995). Moreover, our observation here of dissimilar effects of different neurotrophic stimuli on SGN morphology argues that they act in different intracellular signal pathways. A critical 
question is whether these different signaling pathways ultimately converge on a single molecular regulator of cell survival or whether the cell death machinery is independently regulated at different points by these various intracellular trophic signaling pathways.

\section{Neurotrophic support by depolarization requires cytosolic $\mathrm{Ca}^{2+}$ to be within a set concentration range}

Data presented here indicate that an increase in cytosolic $\mathrm{Ca}^{2+}$ concentration $\left(\left[\mathrm{Ca}^{2+}\right]_{\mathrm{i}}\right.$ ) occurs in response to depolarization of SGNs. Regardless of the means used to depolarize the SGNs, the cellular levels of $\left[\mathrm{Ca}^{2+}\right]_{i}$ are very broadly distributed. This heterogeneity may reflect differing $\mathrm{Ca}^{2+}$ buffering capacities among the cells or differing densities of $\mathrm{Ca}^{2+}$ channels or pumps, perhaps because of differences in frequency-tuning or maturity among the cells.

$\mathrm{Ca}^{2+}$ influx through L-type channels is specifically required for the trophic effect of depolarization on SGNs, as has been shown previously for several types of neurons (Gallo et al., 1987; Collins and Lile, 1989; Koike et al., 1989; Collins et al., 1991). The increase in $\mathrm{Ca}^{2+}$ need not be constant to promote SGN survival; veratridine depolarization supports survival as effectively as depolarization by $30 \mathrm{~mm}\left[\mathrm{~K}^{+}\right]_{\mathrm{o}}$, even though, unlike the latter, veratridine depolarization does not appear to cause a stable increase in $\mathrm{Ca}^{2+}$ but rather an oscillation of $\left[\mathrm{Ca}^{2+}\right]_{i}$ with a periodicity of several minutes. The mechanism underlying this oscillation is unknown.

As with depolarization by $30 \mathrm{~K}$, depolarization by veratridine causes $\left[\mathrm{Ca}^{2+}\right]_{\mathrm{i}}$ to exceed $200 \mathrm{nM}$, but not $350 \mathrm{~nm}$, in most SGNs. This range of $\left[\mathrm{Ca}^{2+}\right]_{\mathrm{i}}$ appears to be critical for survival. Depolarization by $80 \mathrm{~K}$ causes a sustained increase in $\left[\mathrm{Ca}^{2+}\right]_{i}$ greater than that caused by depolarization with veratridine or $30 \mathrm{~mm}$ $\left[\mathrm{K}^{+}\right]_{\mathrm{o}}$. In most SGNs cultured in $80 \mathrm{~K},\left[\mathrm{Ca}^{2+}\right]_{\mathrm{i}}$ exceeds $400 \mathrm{nM}$. A large fraction of SGNs in $80 \mathrm{~K}$ die within $24 \mathrm{hr}$, and this seems to be related to the high $\left[\mathrm{Ca}^{2+}\right]_{\mathrm{i}}$ levels; because the surviving SGNs are those with lower $\left[\mathrm{Ca}^{2+}\right]_{\mathrm{i}}$ levels, most have $\left[\mathrm{Ca}^{2+}\right]_{\mathrm{i}}<350 \mathrm{~nm}$.

These results are comparable with those reported previously for sympathetic neurons (Koike et al., 1989; Koike and Tanaka, 1991), although maximal SGN survival appears to occur at a slightly lower $\left[\mathrm{Ca}^{2+}\right]_{\mathrm{i}}$ than does maximal sympathetic neuronal survival (Franklin et al., 1995). Most important, our data are consistent with the "calcium homeostasis" or "setpoint" hypothesis for neuronal survival proposed by these authors (Koike et al., 1989; Koike and Tanaka, 1991), which is comparable with one proposed earlier for growth cone stability (Kater et al., 1988). Specifically, maintenance of $\left[\mathrm{Ca}^{2+}\right]_{i}$ within a particular range is sufficient for neuronal survival. With $\left[\mathrm{Ca}^{2+}\right]_{i}$ below this range, neurons survive only in the presence of exogenous neurotrophic factors. $\left[\mathrm{Ca}^{2+}\right]_{i}$ exceeding this range results in neuronal death, presumably because of $\mathrm{Ca}^{2+}$-mediated excitotoxicity (Choi, 1988; Siesjo et al., 1989). This is of particular consequence for auditory neurons that have high levels of spontaneous and even higher levels of evoked activity, which could compromise survival through increased $\mathrm{Ca}^{2+}$ influx. Cochlear input to nucleus magnocellularis neurons attenuates $\mathrm{Ca}^{2+}$ influx by a metabotropic glutaminergic postsynaptic mechanism distinct from the glutaminergic excitatory stimulation (Lachica et al., 1995; Zirpel et al., 1995). Other compensatory mechanisms presumably exist in other auditory or highly active neurons.

Although the calcium homeostasis hypothesis can successfully account for the survival or death of neurons in various depolarizing conditions or after exposure to excitatory amino acids (Collins et al., 1991; Koike and Tanaka, 1991; Franklin and Johnson, 1992), Franklin et al. (1995) have suggested recently that the relationship between $\left[\mathrm{Ca}^{2+}\right]_{\mathrm{i}}$ and survival may be more complex. In their study of sympathetic neurons, they found that at high levels of depolarization, in which neuronal survival was poor, the $\left[\mathrm{Ca}^{2+}\right]_{\mathrm{i}}$ level was comparable with the level at lower depolarization, in which survival was good. In that study, $\left[\mathrm{Ca}^{2+}\right]_{i}$ was assessed at $24 \mathrm{hr}$ after shift to depolarizing conditions. Our data also seem to show that $\left[\mathrm{Ca}^{2+}\right]_{\mathrm{i}}$ levels are comparable after $24 \mathrm{hr}$ in $30 \mathrm{~K}$, in which survival is good, and in $80 \mathrm{~K}$, in which survival is poor. However, this is the result of comparing only that selected subpopulation of neurons that survives for $24 \mathrm{hr}$ in $80 \mathrm{~K}$ with neurons cultured for $24 \mathrm{hr}$ in $30 \mathrm{~K}$, which are most of the neurons plated. Only this surviving population has comparable $\left[\mathrm{Ca}^{2+}\right]_{\mathrm{i}}$; most of the neurons in $80 \mathrm{~K}$ had much higher $\left[\mathrm{Ca}^{2+}\right]_{i}$ levels when assessed at $6 \mathrm{hr}$ after depolarization, when all were still alive. Thus, the results of Franklin et al. do not require reassessment of the calcium homeostasis hypothesis. In that study, neurons that did not exhibit high $\left[\mathrm{Ca}^{2+}\right]_{\mathrm{i}}$ after $24 \mathrm{hr}$ in high $\left[\mathrm{K}^{+}\right]_{\mathrm{o}}$ may well be from a population that experienced very high $\left[\mathrm{Ca}^{2+}\right]_{\mathrm{i}}$ levels earlier. Possibly, cells present after $24 \mathrm{hr}$ in high $\left[\mathrm{K}^{+}\right]_{\mathrm{o}}$ are those that initially had lower $\left[\mathrm{Ca}^{2+}\right]_{\mathrm{i}}$ levels. Alternatively, neurons in culture may change their means of regulating $\left[\mathrm{Ca}^{2+}\right]_{\mathrm{i}}$ and could vary in their ability to do so. Additional studies are required to identify those differences among neurons that result in varying survival in high $\left[\mathrm{K}^{+}\right]_{\mathrm{o}}$ and to determine the relationship between regulation of $\left[\mathrm{Ca}^{2+}\right]_{\mathrm{i}}$ and neuronal survival.

A variety of intracellular signals that critically dependents on $\left[\mathrm{Ca}^{2+}\right]_{\mathrm{i}}$ are potential mediators of the trophic effect of depolarization. The robust trophic response of SGNs to depolarization in vitro suggests that they will of value in investigation of these mechanisms. Moreover, the in vivo relevance of mechanisms identified in cultured SGNs can be addressed because of the ease of deafferentation and electrical stimulation of the spiral ganglion in vivo.

\section{REFERENCES}

Avila MA, Varela-Nieto I, Romero G, Mato JM, Giraldez F, Van De Water TR, Represa J (1993) Brain-derived neurotrophic factor and neurotrophin-3 support the survival and neuritogenesis response of developing cochleovestibular ganglion cells. Dev Biol 159:266-275.

Bennett MR, White W (1979) The survival and development of cholinergic neurons in potassium-enriched media. Brain Res 173:549-553.

Bichler E, Spoendlin H, Rauchegger H (1983) Degeneration of cochlear neurons after amikacin intoxication in the rat. Arch Otorhinolaryngol 237:201-208.

Born DE, Rubel EW (1985) Afferent influences on brain stem auditory nuclei of the chicken: neuron number and size following cochlea removal. J Comp Neurol 231:435-445.

Born DE, Rubel EW (1988) Afferent influences on brain stem auditory nuclei of the chicken: presynaptic action potentials regulate protein synthesis in nucleus magnocellularis neurons. J Neurosci 8:901-919.

Bottenstein JE, Sato G (1979) Growth of a rat neuroblastoma cell line in serum-free supplemented medium. Proc Natl Acad Sci USA 76:514-517.

Catsicas M, Péquinot Y, Clarke PGH (1992) Rapid onset of neuronal death induced by blockade of either axoplasmic transport or action potentials in afferent fibers during brain development. J Neurosci 12:4642-4650.

Chalazonitis A, Fischbach GD (1980) Elevated potassium induces morphological differentiation of dorsal root ganglionic neurons in dissociated cell culture. Dev Biol 78:172-183.

Choi DW (1988) Calcium-mediated neurotoxicity: relationship to spe- 
cific channel types and role in ischemic damage. Trends Neurosci 11:465-467.

Collins F, Lile JD (1989) The role of dihydropyridine-sensitive voltage gated calcium channels in potassium mediated neuronal survival. Brain Res 502:99-108.

Collins F, Schmidt MF, Guthrie PB, Kater SB (1991) Sustained increase in intracellular calcium promotes neuronal survival. $J$ Neurosci 11:2582-2587.

Conover JC, Erickson JT, Katz DM, Bianchi LM, Poueymirou WT, McClain J, Pan L, Helgren M, Ip NY, Boland P, Friedman B, Wiegand S, Vejsada R, Kato AC, DeChiara TM, Yancopoulos GD (1995) Neuronal deficits, not involving motor neurons, in mice lacking BDNF and/or NT4. Nature 375:235-238.

Ernfors P, Van De Water T, Loring J, Jaenisch R (1995) Complementary roles of BDNF and NT-3 in vestibular and auditory development. Neuron 14:1153-1164.

Fariñas I, Jones KR, Backus C, Wang X-Y, Reichardt LF (1994) Severe sensory and sympathetic deficits in mice lacking neurotrophin-3. Nature 369:658-661.

Franklin JL, Johnson Jr EM (1992) Suppression of programmed neuronal death by sustained elevation of cytoplasmic calcium. Trends Neurosci 15:501-508.

Franklin JL, Sanz-Rodriguez C, Juhasz A, Deckwerth TL, Johnson Jr EM (1995) Chronic depolarization prevents programmed death of sympathetic neurons in vitro but does not support growth: requirement for $\mathrm{Ca}^{2+}$ influx but not Trk activation. J Neurosci 15:643-664.

Furber S, Oppenheim RW, Prevette D (1987) Naturally-occurring neuron death in the ciliary ganglion of the chick embryo following removal of preganglionic input: evidence for the role of afferents in ganglion cell survival. J Neurosci 7:1816-1832.

Galli C, Meucci O, Scorziello A, Werge TM, Calissano P, Schettini G (1995) Apoptosis in cerebellar granule cells is blocked by high $\mathrm{KCl}$, forskolin, and IGF-1 through distinct mechanisms of action: the involvement of intracellular calcium and RNA synthesis. J Neurosci 15:1172-1179.

Galli-Resta L, Ensini M, Fusco E, Gravina A, Margheritti B (1993) Afferent spontaneous electrical activity promotes the survival of target cells in the developing retinotectal system of the rat. $\mathrm{J}$ Neurosci 13:243-250.

Gallo V, Kingsbury A, Balazs R, Jorgensen OS (1987) The role of depolarization in the survival and differentiation of cerebellar granule cells in culture. J Neurosci 7:2203-2213.

Greene LA, Drexler SA, Connolly JL, Rukenstein A, Green SH (1986) Selective inhibition of responses to nerve growth factor and of microtubule-associated protein phosphorylation by activators of adenylate cyclase. J Cell Biol 103:1967-1978.

Grynkiewicz G, Poenie M, Tsien RY (1985) A new generation of $\mathrm{Ca}^{2+}$ indicators with greatly improved fluorescence properties. J Biol Chem 260:3440-3450.

Han D-Y, Harada N, Tomoda K, Yamashita T (1994) Characterization of the calcium influx induced by depolarization of guinea pig cochlear spiral ganglion cells. ORL J Otorhinolaryngol Relat Spec 56:125-129.

Hartshorn DO, Miller JM, Altschuler RA (1991) Protective effect of electrical stimulation in the deafened guinea pig cochlea. Otolaryngol Head Neck Surg 104:311-319.

Hisashi K, Nakagawa T, Yasuda T, Kimitsuki T, Komune S, Komiyama S (1995) Voltage dependent $\mathrm{Ca}^{2+}$ channels in the spiral ganglion cells of guinea pig cochlea. Hearing Res 91:196-201.

Johnson EM, Deckworth TL (1993) Molecular mechanisms of developmental neuronal death. Annu Rev Neurosci 16:31-46.

Kater SB, Mattson MP, Cohan C, Connor J (1988) Calcium regulation of the neuronal growth cone. Trends Neurosci 11:315-321.

Koike T, Tanaka S (1991) Evidence that nerve growth factor dependence of sympathetic neurons for survival in vitro may be determined by levels of cytoplasmic free $\mathrm{Ca}^{2+}$. Proc Natl Acad Sci USA 88:3892-3896.

Koike T, Martin DP, Johnson Jr EM (1989) Role of $\mathrm{Ca}^{2+}$ channels in the ability of membrane depolarization to prevent neuronal death induced by trophic-factor deprivation: evidence that levels of internal $\mathrm{Ca}^{2+}$ determine nerve growth factor dependence of sympathetic ganglion cells. Proc Natl Acad Sci USA 86:6421-6425.

Koitchev K, Guilhaume A, Cazals Y, Aran J-M (1982) Spiral ganglion changes after massive aminoglycoside treatment in the guinea pig. Counts and ultrastructure. Acta Otolaryngol 94:431-438.

Lachica EA, Rubsamen R, Zirpel L, Rubel EW (1995) Glutamatergic inhibition of voltage-operated calcium channels in the avian cochlear nucleus. J Neurosci 15:1724-1734.

Leake PA, Hradek GT, Rebscher SJ, Snyder RL (1991) Chronic intracochlear electrical stimulation induces selective survival of spiral ganglion neurons in neonatally deafened cats. Hearing Res 54:251-271.

Leake PA, Snyder RL, Hradek GT, Rebscher SJ (1992) Chronic intracochlear electrical stimulation in neonatally deafened cats: effects of intensity and stimulating electrode location. Hearing Res 64:99-117.

Lefebvre PP, Van de Water TR, Weber T, Rogister B, Moonen G (1991) Growth factor interactions in cultures of dissociated adult acoustic ganglia: neuronotrophic effects. Brain Res 567:306-312.

Lefebvre PP, Malgrange B, Staecker H, Moghadass M, Van De Water TR, Moonen G (1994) Neurotrophins affect survival and neuritogenesis by adult injured auditory neurons in vitro. NeuroReport 5:865-868.

Lipton SA (1986) Blockade of electrical activity promotes the death of mammalian retinal ganglion cells in culture. Proc Natl Acad Sci USA 83:9774-9778.

Lousteau RJ (1987) Increased spiral ganglion cell survival in electrically stimulated deafened guinea pig cochleae. Laryngoscope 97:836-842.

Lustig LR, Leake PA, Snyder RL, Rebscher SJ (1994) Changes in the cat cochlear nucleus following neonatal deafening and chronic intracochlear electrical stimulation. Hearing Res 74:29-37.

Maderdrut JL, Oppenheim RW, Prevette D (1988) Enhancement of naturally-occurring cell death in the sympathetic and parasympathetic ganglia of the chicken embryo following blockade of ganglionic transmission. Brain Res 444:189-194.

Meriney SD, Pilar G, Ogawa M, Nunez R (1987) Differential neuronal survival in the avian ciliary ganglion after chronic acetylcholine receptor blockade. J Neurosci 7:3840-3849.

Pasic TR, Rubel EW (1989) Rapid changes in cochlear nucleus cell size following blockade of auditory nerve electrical activity in gerbils. J Comp Neurol 283:474-480.

Pirvola U, Arumae U, Moshnyakov M, Palgi J, Saarma M, Ylikoski J (1994) Coordinated expression and function of neurotrophins and their receptors in the rat inner ear during target innervation. Hearing Res 75:131-144.

Rubel EW, Hyson RL, Durham D (1990) Afferent regulation of neurons in the brain stem auditory system. J Neurobiol 21:169-196.

Rueda J, De La Sen C, Juiz JM, Merchán JA (1987) Neuronal loss in the spiral ganglion of young rats. Acta Otolaryngol 104:417-421.

Ruitjer JM, Baker RE, De Jong BM, Romijn HJ (1991) Chronic blockade of bioelectric activity in neonatal rat cortex grown in vitro. Morphological effects. Int J Dev Neurosci 9:331-338.

Rydel RE, Greene LA (1988) cAMP analogs promote survival and neurite outgrowth in cultures of rat sympathetic and sensory neurons independently of nerve growth factor. Proc Natl Acad Sci USA 85:1257-1261.

Schecterson LC, Bothwell M (1994) Neurotrophin and neurotrophin receptor mRNA expression in developing inner ear. Hearing Res 73:92-100.

Schmidt MF, Kater SB (1993) Fibroblast growth factors, depolarization, and substratum interact in a combinatorial way to promote neuronal survival. Dev Biol 158:228-237.

Schmidt MF, Kater SB (1995) Depolarization and laminin independently enable bFGF to promote neuronal survival through different second messenger pathways. Dev Biol 168:235-246.

Scott BS, Fisher KC (1970) Potassium concentration and number of neurons in cultures of dissociated ganglia. Exp Neurol 27:16-22.

Sie KC, Rubel EW (1992) Rapid changes in protein synthesis and cell size in the cochlear nucleus following eighth nerve activity blockade or cochlea ablation. J Comp Neurol 320:501-508.

Siesjo BK, Bengtsson F, Grampp W, Theander S (1989) Calcium, excitotoxins, and neuronal death in the brain. Ann NY Acad Sci 568:234-251.

Spoendlin H (1975) Retrograde degeneration of the cochlear nerve. Acta Otolaryngol 79:266-275.

Steward O, Rubel EW (1985) Afferent influences on brain stem auditory nuclei of the chicken: cessation of amino acid incorporation as an antecedent to age-dependent transneuronal degeneration. J Comp Neurol 231:385-395.

Vazquez E, Van de Water TR, Del Valle M, Vega JA, Staecker H, Giráldez F, Represa J (1994) Pattern of trkB protein-like immunoreactivity in vivo and the in vitro effects of brain-derived neurotrophic 
factor (BDNF) on developing cochlear and vestibular neurons. Anat Embryol 189:157-167.

Wakade AR, Edgar D, Thoenen H (1983) Both nerve growth factor and high $\mathrm{K}^{+}$concentrations support the survival of chick embryo sympathetic neurons. Evidence for a common mechanism of action. Exp Cell Res 144:377-384.

Webster M, Webster DB (1981) Spiral ganglion neuron loss following organ of Corti loss: a quantitative study. Brain Res 212:17-30.

Wheeler EF, Bothwell M, Schecterson LC, von Bartheld CS (1994) Expression of BDNF and NT-3 mRNA in hair cells of the organ of Corti: quantitative analysis in developing rats. Hear Res 73:46-56.

Wong-Riley MTT, Walsh SM, Leake-Jones PA (1981) Maintenance of neuronal activity by electrical stimulation of unilaterally deafened cats demonstrable with cytochrome oxidase technique. Ann Otol Rhinol Laryngol 90:30-32.

Wright L (1981) Cell survival in chick embryo ciliary ganglion is reduced by chronic ganglionic blockade. Dev Brain Res 1:283-286.

Ylikoski J, Pirvola U, Moshnyakov M, Palgi J, Arumäe U, Saarma M (1993) Expression patterns of neurotrophin and their receptor mRNAs in the rat inner ear. Hearing Res 65:69-78.

Zheng JL, Stewart RR, Gao W-Q (1995) Neurotrophin-4/5 enhances survival of cultured spiral ganglion neurons and protects them from cisplatin neurotoxicity. J Neurosci 15:5079-5087.

Zirpel L, Lachica EA, Lippe WR (1995) Deafferentation increases the intracellular calcium of cochlear nucleus neurons in the embryonic chick. J Neurophysiol 74:1355-1357. 